\title{
29. QUATERNARY NANNOFOSSILS FROM GOBAN SPUR, EASTERN NORTH ATLANTIC OCEAN, DEEP SEA DRILLING PROJECT HOLES 548 AND 549A ${ }^{1}$
}

\author{
Annick Pujos, Département de Géologie et Océanographie, Institut de Géologie du Bassin d’Aquitaine, Université \\ de Bordeaux $\mathrm{I}^{2}$
}

\begin{abstract}
At Holes 548 and 549A, almost complete sections of Quaternary deposits were recovered. Floral associations were studied in closely spaced samples. Nannofossils are moderately well preserved and contain few reworked forms. The following nannofossils were studied in detail: Gephyrocapsa (closed Gephyrocapsa with G. producta, G. sinuosa, and $G$. caribbeanica; open Gephyrocapsa: G. doronicoides, subdivided into five variants, and G. oceanica; G. protohuxleyi; small Gephyrocapsa: G. ericsonii and G. aperta), Pseudoemiliania lacunosa (a round and an elliptical type), Helicopontosphaera $(H$. sellii, $H$. gr. kamptneri, and $H$. neogranulata), Cyclococcolithina (three variants of $C$. leptopora and two variants of $C$. macintyrei), Coccolithus pelagicus ( $C$. pelagicus s.s. and two variants). These taxa were used to define supplementary datum levels to be added to the conventional nannofossil datums and to the paleomagnetic events on the curves of sediment accumulation rate for each site. Thus, it is possible to establish a tentative, very detailed nannofossil stratigraphy for the Quaternary. The influence of glaciation on the calcareous phytoplankton is evident, especially during the last 500,000 yrs. The nannofossil total-abundance curve shows fluctuations that resemble closely the fluctuations in the major climatic cycles described by Ruddiman and McIntyre (1976).
\end{abstract}

\section{INTRODUCTION}

Holes 548 and 549A were drilled during Leg 80 on the Goban Spur, on the northern margin of the Bay of Biscay (Fig. 1). The upper part of the recovered sediments consists of thick Quaternary sections with abundant coccoliths. These nannofossil assemblages can be used to establish a detailed stratigraphic scale for the Quaternary.

Several Pleistocene stratigraphic zonations have been established; the best known are those developed by Martini and Worsley (1970) and Okada and Bukry (1980), which are applicable worldwide. Other, more detailed, studies are more local in focus (Samtleben, 1978: Sierra Leone Rise; Pujos-Lamy, 1977: Bay of Biscay; Gartner, 1977: various oceans). To define a detailed zonation, continuous deep-water sections that accumulated at high sedimentation rates are needed. Holes 548 and 549A proved to be excellent for such studies, despite their geographical location, at high latitude and close to a continent, which implies the influence of glaciation and subsequently a discontinuity of development of the phytoplankton population. This location can, however, be used as a reference section to correlate nannofossil variations and climatic events already studied (as correlations can be developed between planktonic foraminifer variations and oxygen-isotope analyses) (Emiliani, 1955, 1966; Shackleton and Opdyke, 1973; Morley and Hays, 1981).

\section{METHODS}

Material from Holes 548 and 549A was sampled in detail ( 200 samples from Hole 548 and 80 samples from Hole 549A). Smear slides

\footnotetext{
${ }^{1}$ Graciansky, P. C. de, Poag, C. W., et al., Init. Repts. DSDP, 80: Washington (U.S. Govt, Printing Office).

2 Address: Département de Géologie et Océanographie, Institut de Géologie du Bassin d'Aquitaine, Université de Bordeaux 1, Avenue des Facultès, 33405 Talence Cedex, France.
}

were used to examine nannofossils with a light microscope $(\times 1200)$. Total abundance was estimated on a single field of view, and species abundance was estimated on 20 fields of view. Tables 1 and 2 give an account of these estimates, designated as follows: rare (fewer than 4 specimens), frequent (4-9 specimens), common (10-15 specimens) and abundant (more than 15 specimens). These estimates are more detailed on Figures 2 and 3. Percentage evaluation is omitted for two reasons: (1) some taxa (mostly Gephyrocapsa) are very dominant in the nannofossil assemblages, which means that all the percentages of other taxa are low. These species (which are often present, but in small amount) would always be represented by percentages less than $1 \%$, obscuring their variations in abundance. Minimizations or even eliminations of these low-ratio taxa would, consequently, modify the population pattern and its significance; (2) at some levels, the number of taxa is so low that we cannot describe the population in percentages. This phenomenon has already been described by McIntyre et al. (1972); the authors associate these "barren zones" with glacial periods. Since the sites are at high latitudes, the influence of glaciation, which can greatly reduce the abundance and diversity of nannofossil assemblages, may be important.

Some 40 samples were examined with an electron microscope (scanning [SEM] and transmission [TEM]) to separate accurately the $G e$ phyrocapsa and the Cyclococcolithina species. In many instances, a light microscope proved to be sufficient to determine nannofossils in stratigraphic studies.

\section{PRESERVATION}

Preservation of coccoliths is usually moderate. In samples examined with SEM and TEM, the central structures (grids or bars) were usually damaged or even totally destroyed. The edges of the shields often appeared to be dissolved or broken in the Gephyrocapsa group. Some species of this group are characterized by a medium size (about $4 \mu \mathrm{m}$ ) and a thin ring around a large central opening, with or without a "ghost" of a bar. These specimens occur sporadically in Hole 548 (mostly between Sections 548-3-7 and 548-4-6 and between Sections 548-13-2 and 548-15-4) and in Hole 549A (mostly between Sections 549A-1-4 and 549A-2-4 and between Sections 549A-3-3 and 549A-3,CC). These specimens at both sites occur at two levels. At the upper level G. oce- 


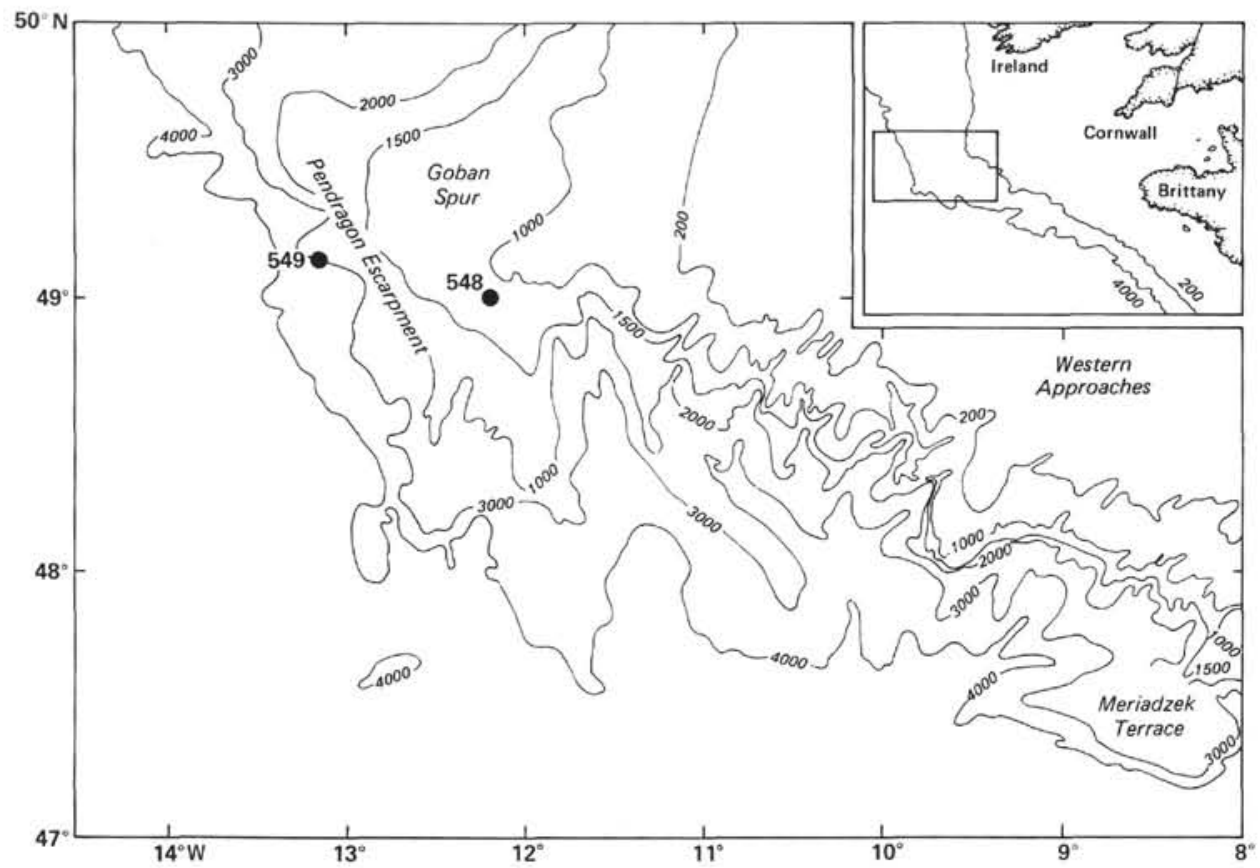

Figure 1. Locations of Holes 548 and 549, drilled during Leg 80. (Contours in meters.)

anica is predominant, and at the lower level G. caribbeanica is abundant. These Gephyrocapsa "ghosts" probably belong to either $G$. oceanica or G. caribbeanica, but this is difficult to determine merely by examining slides.

Another problematic example of dissolution is seen in G. protohuxleyi. Other corroded Gephyrocapsa species (G. oceanica, for example) may resemble G. protohuxleyi, for their outer shield elements are separated, by dissolution, to resemble the configuration in G. protohuxleyi.

Dissolution is at a maximum during glacial periods, when the abundance of nannofossils is low. McIntyre et al. (1972) explain the existence of "barren zones" by low productivity. Although low productivity contributes considerably to the low abundances and the low diversity, strong dissolution also contributes. Monospecific floras of Coccolithus pelagicus (a dissolution-resistant species) may be the result of the disintegration of other, less resistant, coccoliths.

\section{REWORKING}

Reworking is evident throughout the Quaternary sections of Holes 548 and 549A, and it was most significant during glacial periods, when the abundance of autochthonous species was reduced. Reworked coccoliths may be transported by ice-rafting. It is often difficult to identify these reworked coccoliths, for they are generally corroded or broken, a common feature associated with glaciation. But they can be recognized quite easily as Cretaceous or Paleogene. These reworked species are particularly abundant in the upper parts of the sections (above Section 7-3 in Hole 548 and above Section 3-1 in Hole 549A), where a change of the sedimentation pattern occurred at the Goban Spur. Reworking was insignificant during the middle and early Pleistocene. Some
Pliocene Reticulofenestra occur sporadically at the two sites.

\section{DISTRIBUTION OF CALCAREOUS NANNOFOSSILS}

\section{Hole 548}

Hole 548 was drilled in $1256 \mathrm{~m}$ of water, on a slope of the outer southern Irish continental shelf, at $48^{\circ} 54.95^{\prime} \mathrm{N}, 12^{\circ} 09.84^{\prime} \mathrm{W}$. Distribution of nannofossils is summarized in Table 1 and Figure 2.

The Quaternary is represented by the upper $106 \mathrm{~m}$ of the section. The Plio/Pleistocene boundary is difficult to determine exactly, because Discoaster is absent in the upper Pliocene (Müller, this vol.). Below $99.5 \mathrm{~m}$ (Section 14-1), the presence of Cyclococcolithina gr. macintyrei characterizes the lowermost Pleistocene. At such a high latitude, however, the last occurrence of Discoaster cannot be used as a datum level. The Plio/Pleistocene boundary must be determined by paleomagnetic zonation (Townsend, this vol.), and is found at about $105 \mathrm{~m}$ (Section 15-6) (Olduvai).

Some conventional datums give several points of reference, which provide a biostratigraphic basis for subdivision of the section:

- Appearance of Gephyrocapsa oceanica s.l.: here the first $G$. oceanica present is $G$. oceanica "W": 102.4 $\mathrm{m}$ (Section 15-2).

- Extinction of C. macintyrei: $99.5 \mathrm{~m}$ (Section 14-1)

- Extinction of Helicopontosphaera sellii: $89.4 \mathrm{~m}$ $(11, \mathrm{CC})$

- Acme of "small Gephyrocapsa" between $89.4 \mathrm{~m}$ $(11, \mathrm{CC})$ and $79 \mathrm{~m}$ (Section 10-6)

- Extinction of " $C$. jaramillensis" (in Perch-Nielsen, 1972; synonymous with $G$. doronicoides, Bukry, 1970). It seems that this species is not completely extinct at this 
Table 1. Distribution of nannofossils in the Pleistocene of Hole 548.

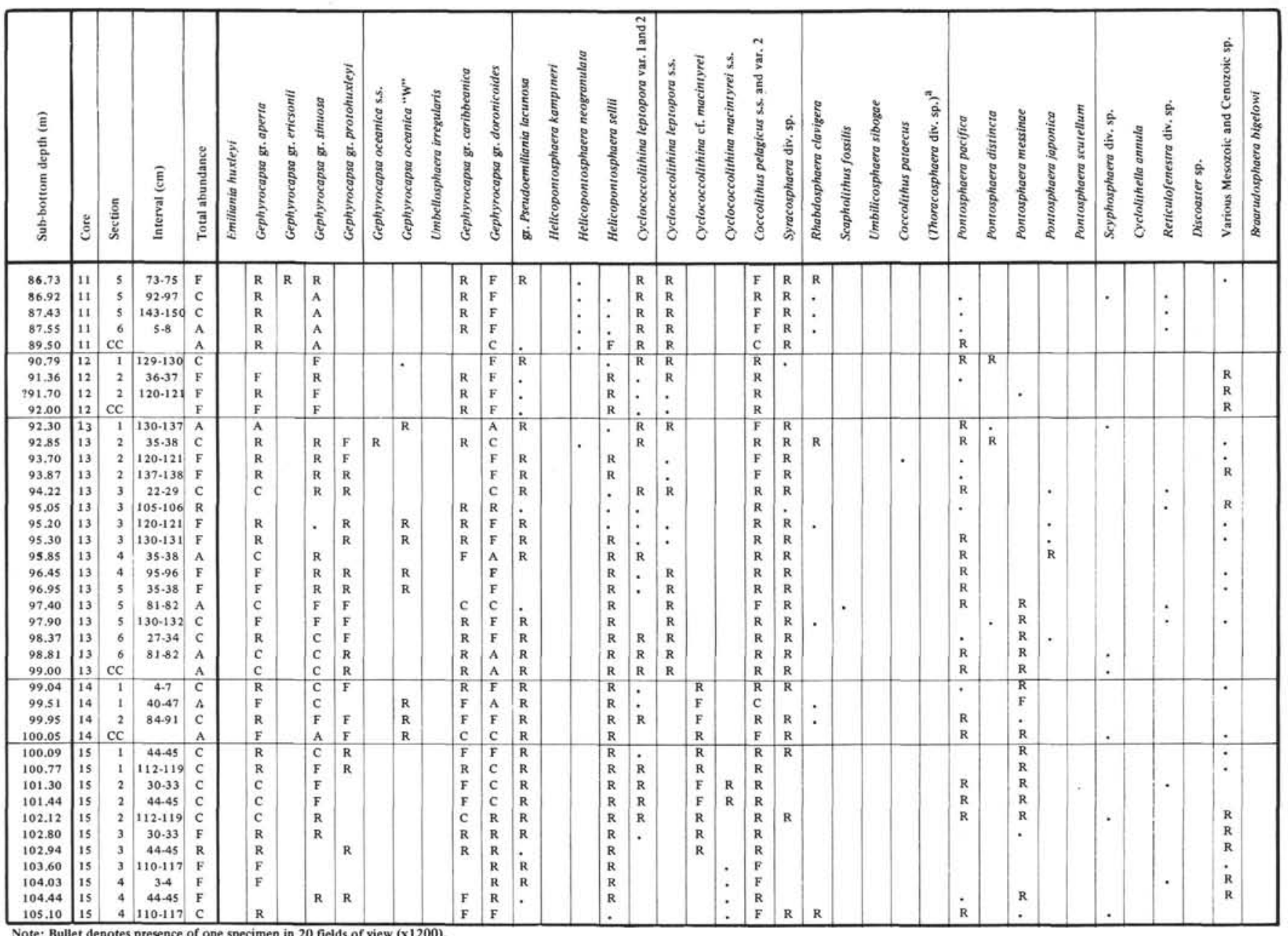

Note: Bullet denotes presence of one specimen in 20 fieids of view (x1200).
${ }^{2}$ Athough this genus is assumed to belong to Dinophyceae, it has been placed among nannofossils, because they are usually observed on the same slides

depth; it represents here only the end of the acme of $G$. doronicoides s.s.: $78.2 \mathrm{~m}$ (Section 10-6).

- Extinction of Pseudoemiliania lacunosa: $58.6 \mathrm{~m}$ (Section 7-5)

- Last peak of Gephyrocapsa caribbeanica: $32.4 \mathrm{~m}$ (Section 4-7)

- Appearance of Umbellosphaera irregularis: $30.8 \mathrm{~m}$ (Section 4-6) (probably local)

- Beginning of acme of Emiliania huxleyi: $13.5 \mathrm{~m}$ (Section 3-1)

In addition to these datums, some other species (or variants) show characteristic variations, appearances, or acmes: For example, the variants of $G$. doronicoides, some small Gephyrocapsa (G. aperta, G. ericsonii, G. sinuosa, G. protohuxleyi), Helicopontosphaera neogranulata, and $C$. pelagicus. Their distribution will be described in detail in the taxonomic section and in the section on the ages of datums.

Besides these biostratigraphic observations, the total nannofossil abundance is plotted in Figure 2. There are few variations in the lower to middle Pleistocene below $58.5 \mathrm{~m}$ (Section 7-5), where high $\mathrm{CaCO}_{3}$ contents correspond to abundant nannofossils; there are only two mini- $\mathrm{ma}$, at 86 to $80.5 \mathrm{~m}$ (Sections 11-5 to 10-1) and at about 77 to $78 \mathrm{~m}$ (Section 10-5). Above $58.5 \mathrm{~m}$ (Section 7-5), in the upper Pleistocene, there are strong fluctuations in the abundance of coccoliths from abundant (Sections 6-4 to $5-4 ; 5-2$ to $5-1 ; 4-3$ to $4-1 ; 3-3$ to $2-6$; and $1-1$ ) to almost barren zones.

\section{Hole 549A}

Hole 549A was drilled in $2535.5 \mathrm{~m}$ of water, near the seaward edge of the Pendragon Escarpment, at $49^{\circ} 05.29^{\prime} \mathrm{N}, 13^{\circ} 05.89^{\prime} \mathrm{W}$. Nannofossil distribution is summarized in Table 2 and Figure 3.

The Quaternary corresponds to the upper $27 \mathrm{~m}$ (three cores) of the section. It is separated by a hiatus from the Miocene at the top of Core 4. The hiatus corresponds to the lower half of the Pleistocene. The lowest part of the section contains abundant and diverse nannofossils. The presence of Pseudoemiliania lacunosa, Gephyrocapsa doronicoides, and Helicopontosphaera neogranulata, the absence of $\mathrm{H}$. sellii, and the abundance of "small $\mathrm{Ge}$ phyrocapsa" permit correlation of the oldest Quaternary sample of Hole 549A with Section 10-5 of Hole 548. 


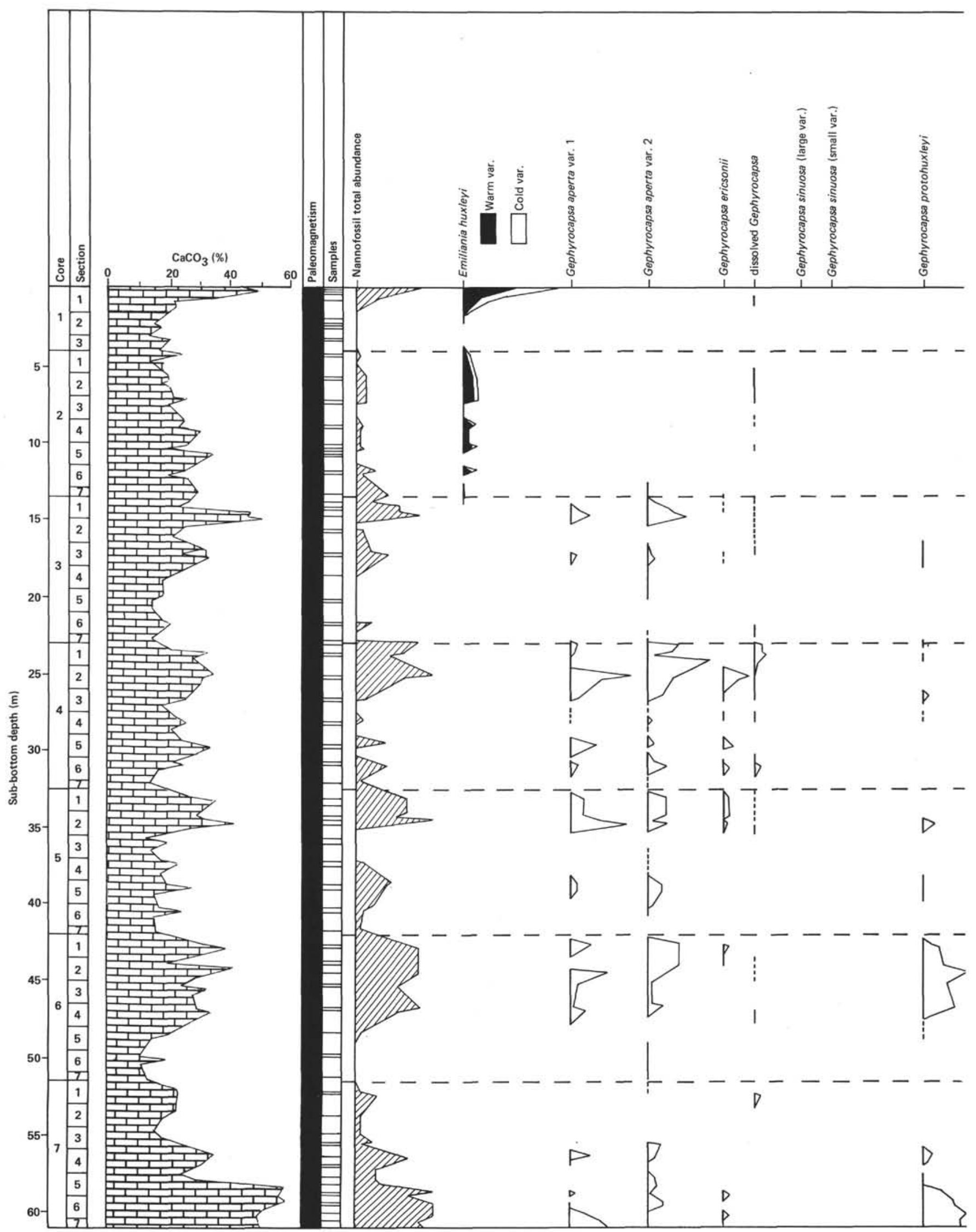

Figure 2. Distribution of Quaternary calcareous nannofossils, Hole 548. 


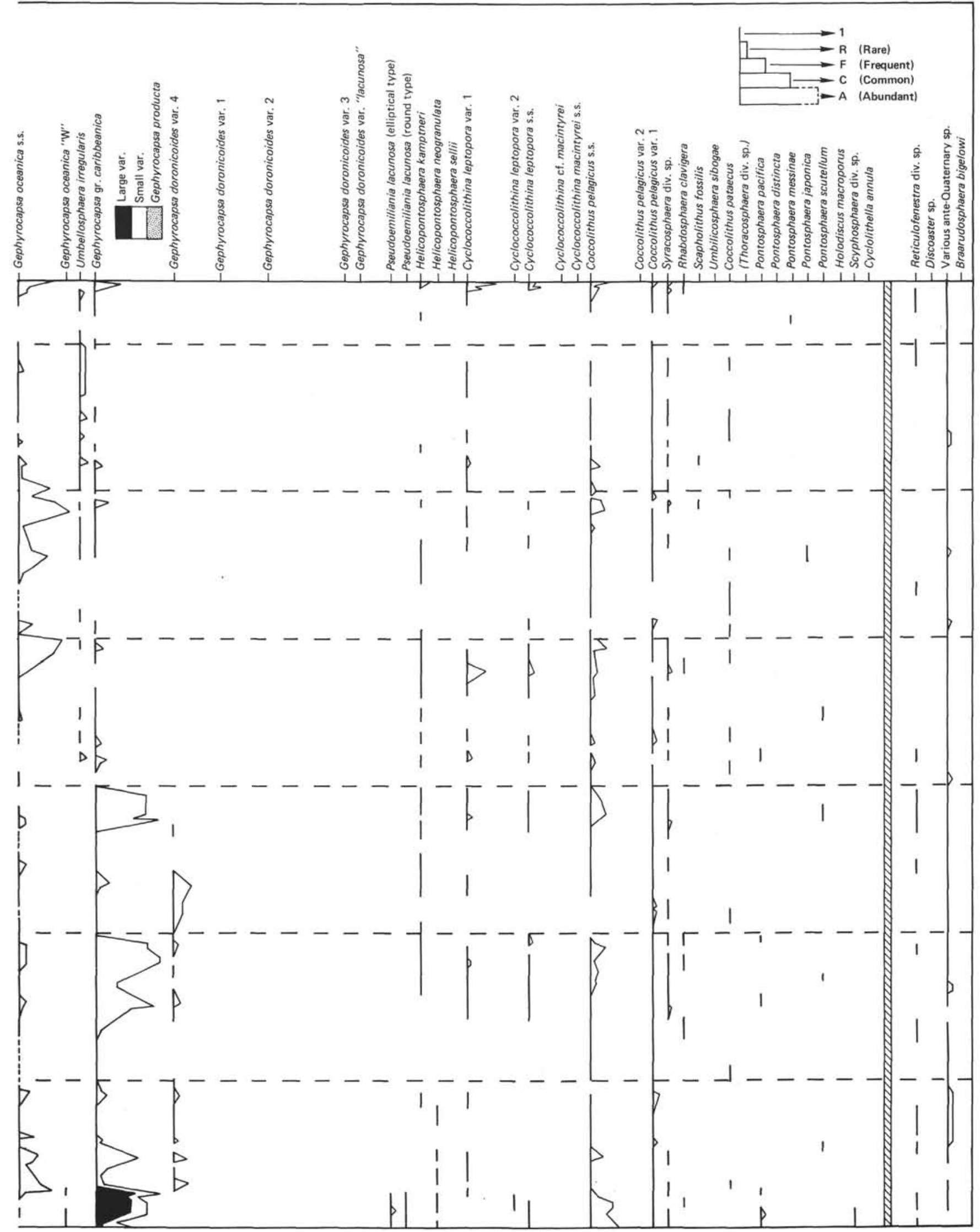

Figure 2. (Continued). 


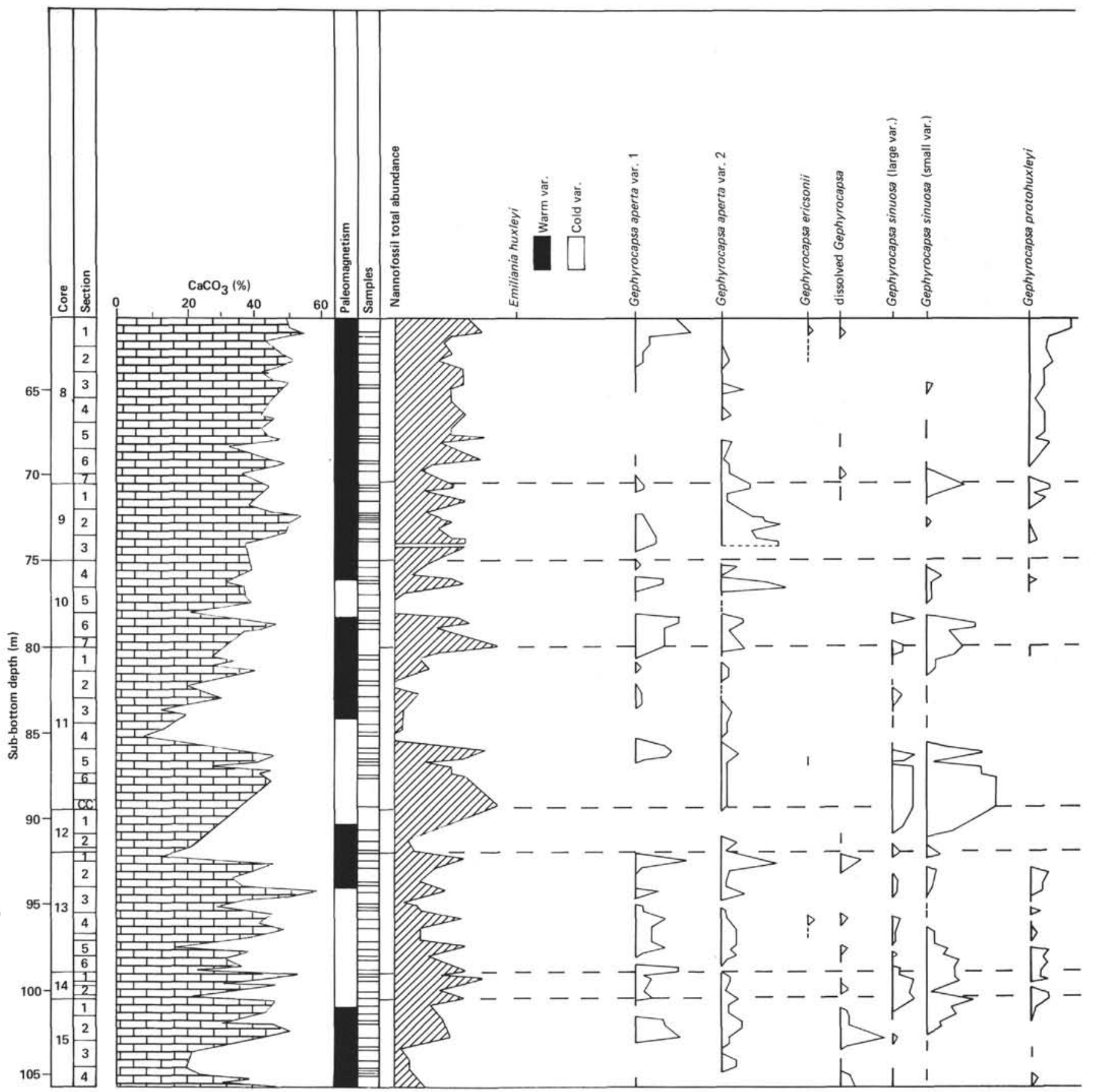

Figure 2. (Continued).

As in Hole 548, conventional and additional markers may be used:

- Top of acme of $G$. doronicoides s.s.: $25.7 \mathrm{~m}$ (Section 3-6)

- Extinction of Pseudoemiliania lacunosa: $20 \mathrm{~m}$ (Section 3-2)

- Last peak of G. caribbeanica: 10.2 m (Section 2-3)

- Appearance of Umbellosphaera irregularis: $9.5 \mathrm{~m}$ (Section 2-2)

- Beginning of acme of Emiliania huxleyi: $5 \mathrm{~m}$ (Section 1-4)
The abundance of nannofossils shows strong fluctuations; nannofossils are very abundant (Sections 3,CC to $3-6$; middle of $3-5 ; 3-4 ; 3-4$ to $3-2 ; 2, \mathrm{CC}$ to base of $2-4$; $2-3 ; 2-1$ to $1, C C ; 1-4$ to $1-3$; top of $1-1$ ) or very rare.

\section{CHARACTERISTICS OF SOME CALCAREOUS NANNOFOSSILS}

\section{The Gephyrocapsa Complex}

Species belonging to this genus occur in the upper Pliocene and cannot, therefore, be used to determine 


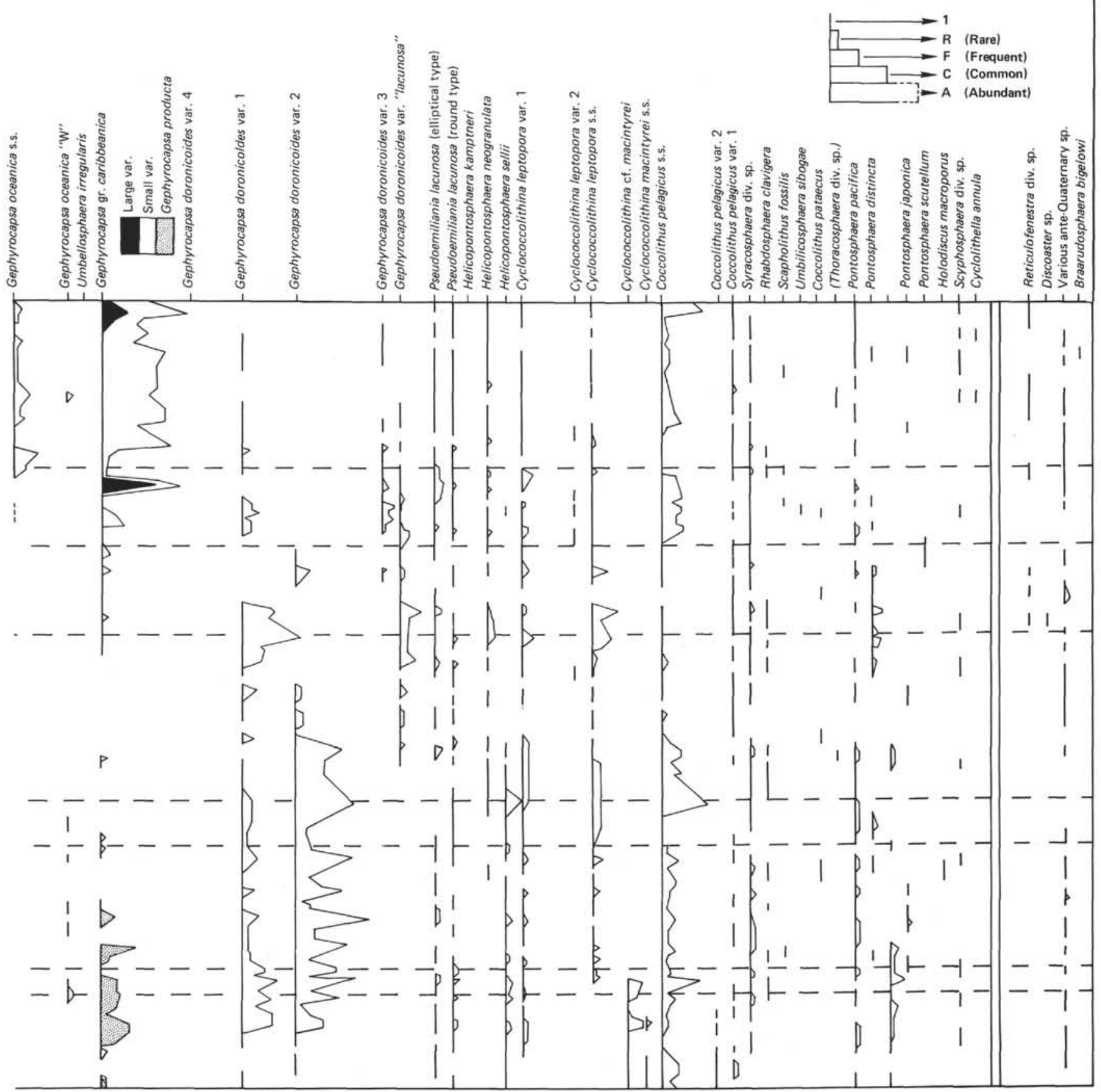

Figure 2. (Continued).

the Plio/Pleistocene boundary. These coccoliths were very abundant from the earliest Pleistocene on, and remained dominant almost until today. According to Gartner (1977), "the genus Gephyrocapsa expanded into the ecological niche left vacant by the extinction of Discoaster brouweri." In this part of the Atlantic, however, disceasters disappeared during the Pliocene NN16, earlier than in many other parts of the ocean. Therefore, the Gephyrocapsa expansion at the beginning of the Quaternary was not the result of a "vacancy" only, but may have resulted either from the disappearance of discoasters or from another ecological factor.
Many Gephyrocapsa species have been described and studied. It is not possible, however, to distinguish these species clearly, even when observations are very detailed. Ecological variants are often considered as taxonomic ones, and the naming of these variants is not always necessary, for it may complicate observation of the distribution. Bréhéret (1978), for example, created two new species from two morphotypes previously described ( $\mathrm{Pu}-$ jos-Lamy, 1976, and Bréhéret, 1977). The use of these new names is to be questioned, because it is evident that those types are either evolutionary steps within the species oceanica and/or caribbeanica or ecophenotypes, and 
Table 2. Distribution of nannofossils in the Pleistocene of Hole 549A.

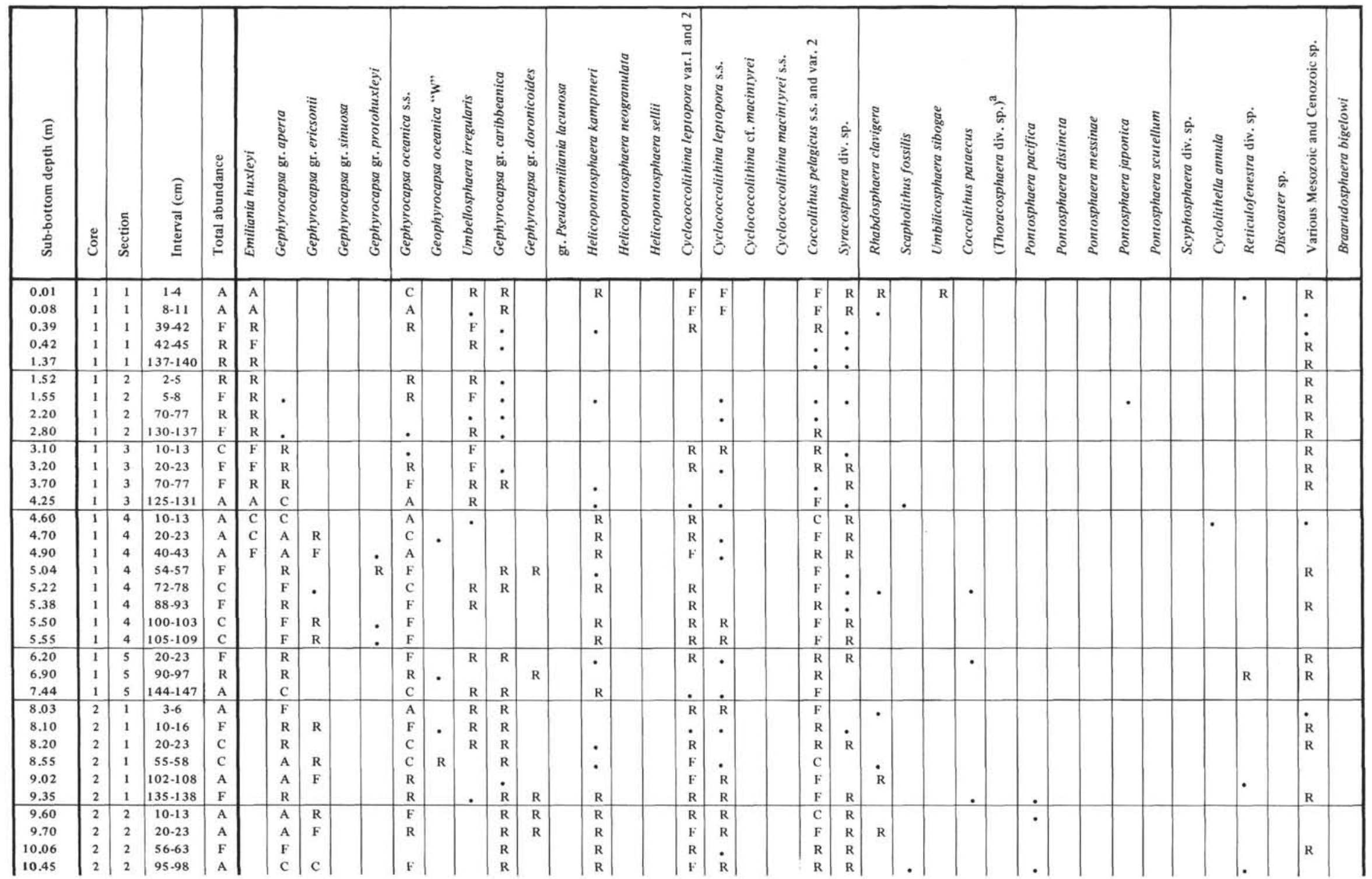




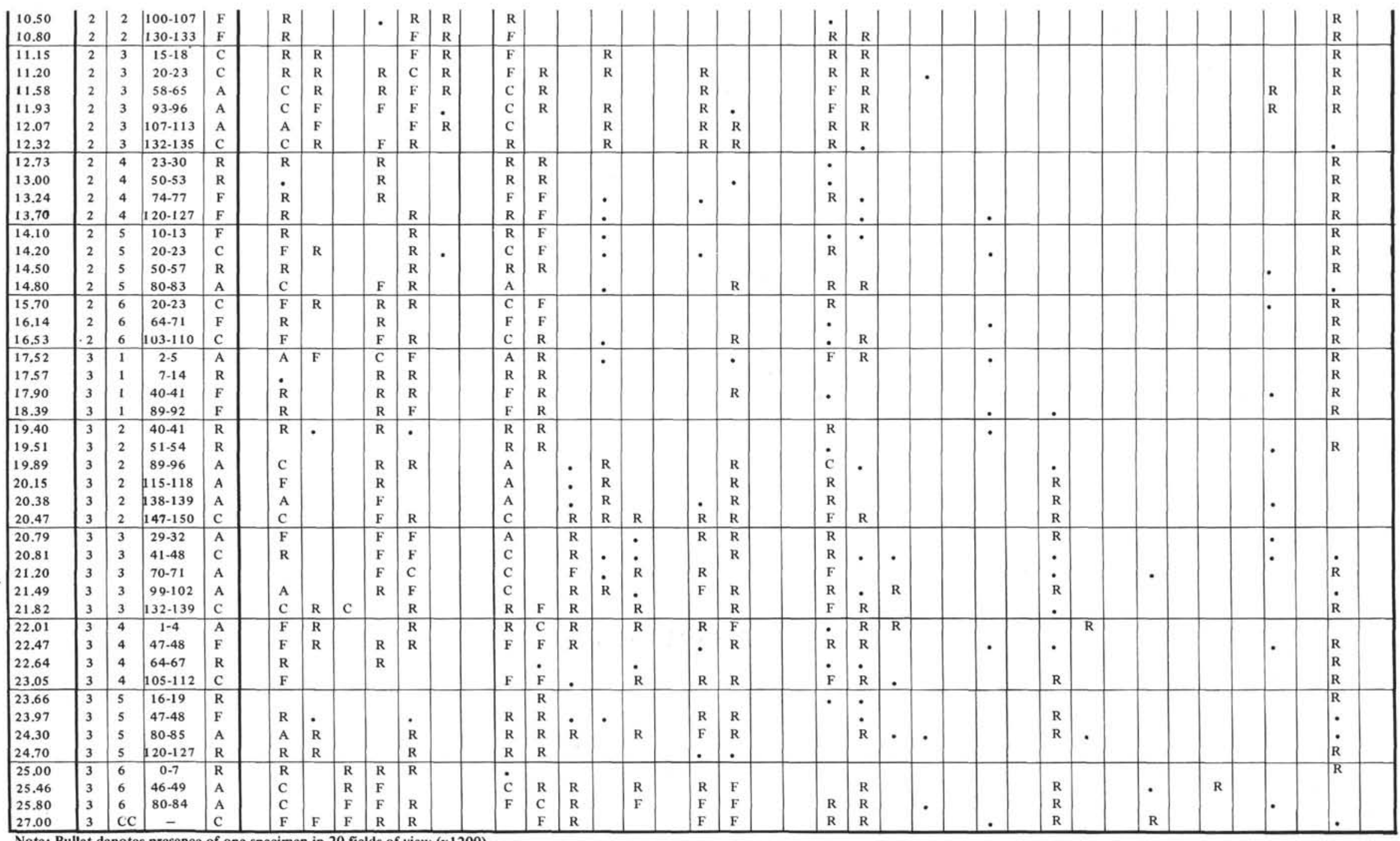

Note: Bullet denotes presence of one specimen in 20 fields of view $(\mathrm{x} 1200)$.

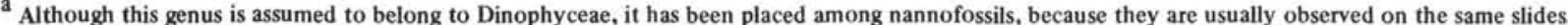




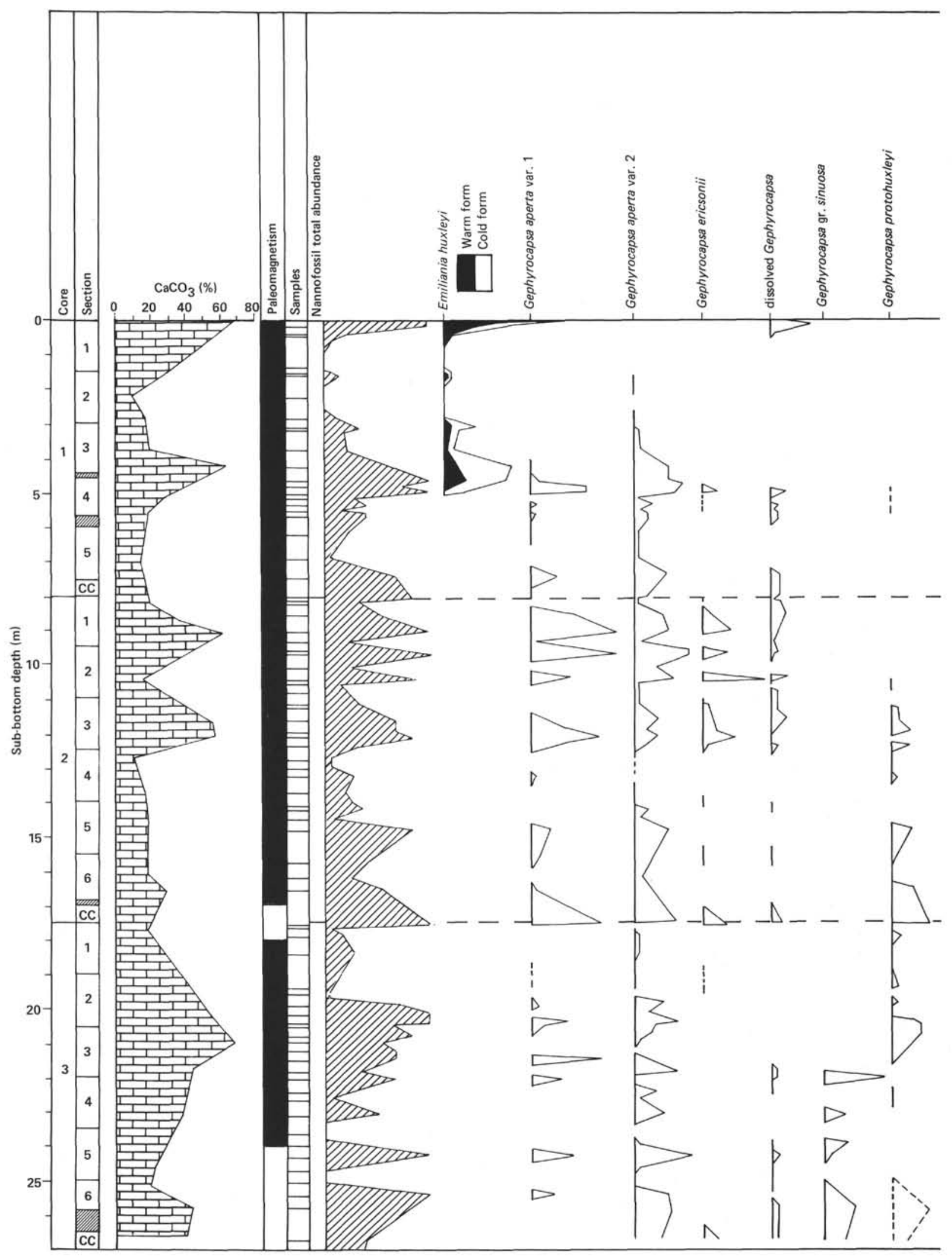

Figure 3. Distribution of Quaternary calcareous nannofossils, Hole 549A. 


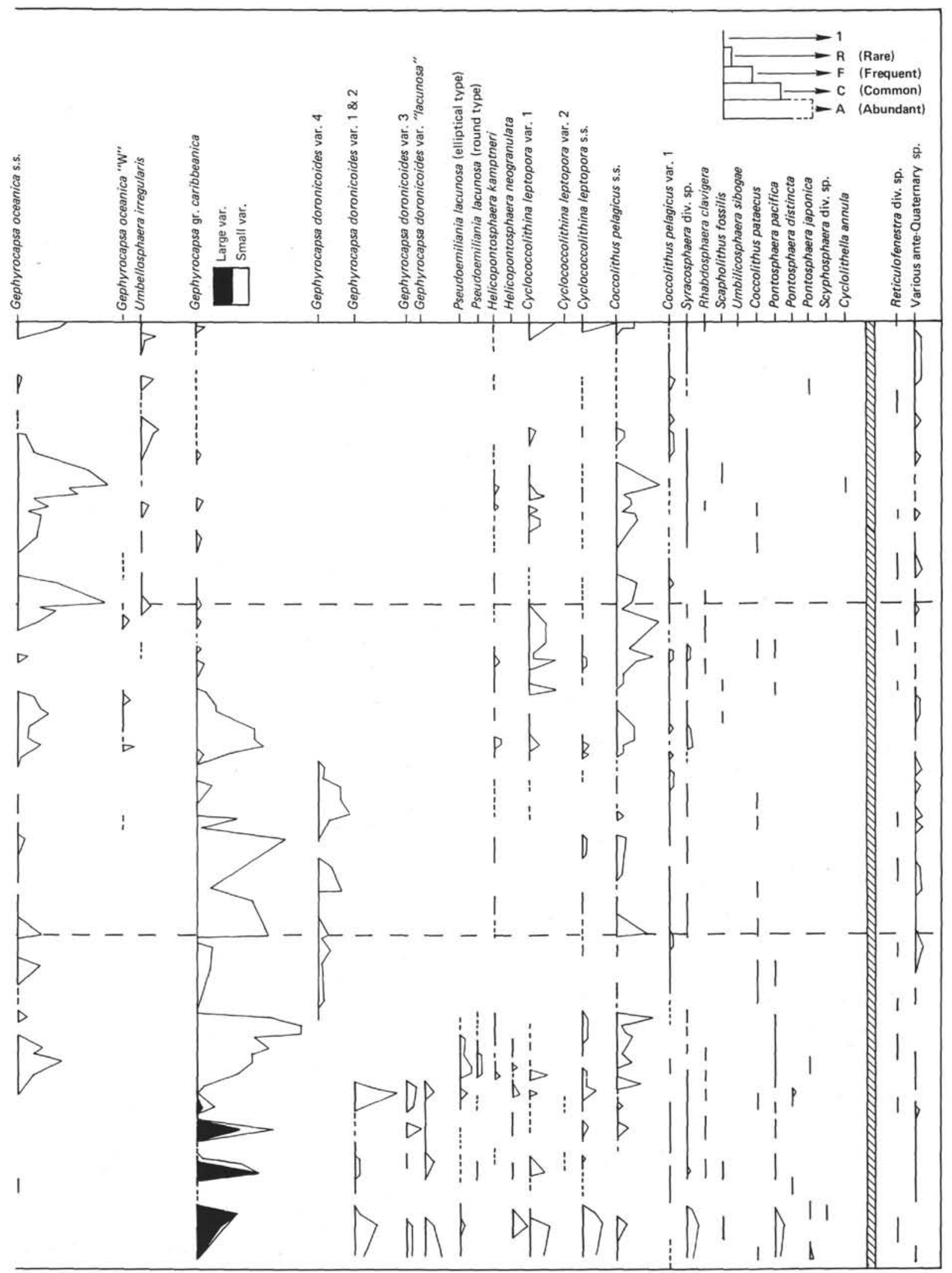

Figure 3. (Continued). 
not real species. It is impossible to use them as worldwide stratigraphic markers. Samtleben (1978) uses these two new species and creates two more new ones; he places all the different species of Gephyrocapsa in one group which begins in the early Pliocene.

The increase in the number of species is useful, provided these species can be categorized in "morphogroups" (as has been done by, e.g., Gartner [1977] and Bukry [1973]), and offers the possibility of following the evolution of the genus, step by step. Gartner (1977) employed the terms "closed and open Gephyrocapsa," which are very useful; they concern two "stocks" of coccoliths having a general morphology, an evolutionary pattern, and a history of their own. Evolution of both closed and open Gephyrocapsa species starts off from specimens free of a bar; this bar appears gradually, following slow and continuous modifications of central shield elements. For this reason alone, I place all these coccoliths-with or without a bar-within the same $\mathrm{Ge}$ phyrocapsa genus.

Bukry (1973), too, distinguishes two groups: (1) a group in the early Quaternary with small openings in the central area ( $=$ G. caribbeanica, G. lumina, $G$. produc$t a$ ), and (2) a group "later in the Quaternary" with large openings in the central area ( $=G$. aperta, G. oceanica, $G$. omega). A third group with an elevated bar $(=G$. ericsonii) appears in the latest Quaternary (McIntyre and Bé, 1967).

In this study, distinguishing between "closed" and "open" Gephyrocapsa proved useful. In addition, two other groups were recognized: "small Gephyrocapsa," characterized by their limited size, and the "G. protohuxleyi" group, characterized by the typical morphology of their coccoliths.

Overall characteristics and distribution of the morphotypes are given in Table 3.

\section{Closed Gephyrocapsa}

The closed Gephyrocapsa group occurred as early as the beginning of the Pleistocene. It seems to have evolved from some Dictyococcites from the late Pliocene. At the beginning, closed coccoliths were rather small, without a central opening, and with a rough crossbar ( $G$. pro$d u c t a$ ). The next step may have been $G$. sinuosa, a small form with a pre-cement crossbar, which constitutes most of the "small Gephyrocapsa" of the zone of Gartner (1977). The last "closed" morphotype is G. caribbean$i c a$, which is by itself a complex group (Pujos-Lamy, 1976); here there is a beginning of a central opening and a well-individualized crossbar.

\section{Open Gephyrocapsa}

The open Gephyrocapsa are divided into two main species:

1. G. doronicoides, derived from the Pliocene "Reticulofenestra doronicoides." The two taxa are morphologically similar; the only difference is a crossbar, more or less individualized, in the Pliocene Gephyrocapsa doronicoides. At the Leg 80 sites, the coccoliths within the doronicoides group show few minor variations, which are used not to describe species but to distinguish five variants (see Table 3 ).

2. G. oceanica is the typical "open Gephyrocapsa." Compared with the $G$. doronicoides taxon, G. oceanica has a larger central opening, a crossbar easier to observe, and far more regular elements in the proximal shield. Two morphotypes, possibly related to climatic factors, are distinguished. G. oceanica "W" has a larger opening, and may be a "warm" ecophenotype (see Table 3); G. oceanica s.s. may be more cosmopolitan.

\section{Gephyrocapsa protohuxleyi}

G. protohuxleyi raises another problem. According to the available published photographs (McIntyre, 1970), variations are evident: size, shape of the elements, central opening, and crossbar vary greatly. It is possible that the typical shape of the elements results from dissolution or ecological variations within the species rather than from the morphology of coccoliths of a distinct species while still alive (Winter et al., 1978).

For the Leg 80 samples, the name of G. protohuxleyi is given to all specimens with a characteristic element shape. Certain morphological and size variations may be recognized:

1. Between 548-15-1 and 548-13-2, G. protohuxleyi has the same size as $G$. producta. The central area is almost or completely closed. It does not seem to have a crossbar.

2. Between 548-9-3 and 548-6-1, G. protohuxleyi is of medium size. The central area is open. When the crossbar exists, it looks like that of G. caribbeanica.

This distribution suggests that $G$. protohuxleyi is an ecophenotype rather than a distinct species. Its characteristic morphology could result from the influence of ecological factors on a number of species of the closed group (in this case, they could be G. caribbeanica/G. producta); according to Winter et al. (1978), salinity could perhaps be the causal factor.

\section{Small Gephyrocapsa}

The small Gephyrocapsa group is composed of the G. aperta s.1. and G. ericsonii species, which have been described earlier together with their variants (Pujos-Lamy, 1976). G. aperta var. 1 and 2 are very abundant from the lower Fleistocene to 548-3-1 and 549A-1-3. G. ericsonii appears at 548-8-1 and 549A-3-2, and disappears almost at the same level as $G$. aperta.

Gartner (1977) described a "small Gephyrocapsa zone" in the lower Pleistocene. A similar zone also exists at the Leg 80 sites, but the "small Gephyrocapsa" species with an important acme is designated here to be G. sinuosa, which I consider part of the $G$. caribbeanica group. $G$. sinuosa coccoliths are larger than $G$. aperta/ericsonii coccoliths.

\section{Other Gephyrocapsa Species}

A fifth Gephyrocapsa group was observed under the light microscope. In this group, as in G. protohuxleyi, coccolith size varies throughout the Pleistocene. The group shares characteristics with the Gephyrocapsa group 
as a whole: shields are thin, with a relatively large central opening; the crossbar is often absent, but whenever present it is very thin, with a variable orientation.

SEM observation indicates that this is not a true species, but consists of dissolved Gephyrocapsa coccoliths of G. producta between 548-15-4 and 548-13-1, and of G. oceanica between 548-4-6 and 548-4-1.

This "species" is not included in Tables 1 and 2, but it is shown in Figure 2 and 3 because it reveals the effect of dissolution on nannofossils.

\section{The Pseudoemiliania lacunosa Complex}

The Pseudoemiliania lacunosa complex consists of at least two different taxa. In 1973, Bukry stated that Emiliania and Pseudoemiliania placoliths are the same and that consequently the latter term should not be used, since it is a synonym of the former. Gartner (1977) considered this problem carefully and concluded that Pseudoemiliania is valid and should be maintained in its original use, a conclusion with which I agree. Furthermore, Gartner distinguishes two morphotypes within the lacunosa complex: one round and the other elliptical. Both morphotypes have radial slits between elements of the distal shield. Bukry (1971 and later) calls these types Emiliania annula (Cohen) and Emiliania ovata Bukry, terms which Gartner considers pointless, for both types have an almost identical distribution.

Nevertheless, the two types are morphologically different. The round type is rather large (diameter 6 to 7 $\mu \mathrm{m}$ ); its central area is large (diameter of the opening = 3-4 $\mu \mathrm{m}$ ) and surrounded by shields corresponding to less than one third of the total coccolith surface. Slits are numerous. This type agrees very well with the description of the genus and of the type species lacunosa.

The elliptical type is slightly smaller than the round one; its central opening is small and slits are few. Coccoliths resemble those of $G$. doronicoides in shape, especially one variant of this species, named $G$. doronicoides var. "lacunosa." A difference between variant and the elliptical $P$. lacunosa is in the number of slits, which is less for $G$. doronicoides var. "lacunosa." Moreover, $P$. lacunosa never has a crossbar.

Judging from the morphologies of both types, it appears that they belong to two different lineages. The elliptical type was derived from $G$. doronicoides in the Pliocene, evolved during the late Pliocene, and is coeval with some variants of the parent species. Sometimes, distinguishing between $P$. lacunosa, elliptical type, and G. doronicoides var. "lacunosa" is difficult.

The origin of the circular type is difficult to determine; perhaps it is descended from an ancestor other than the elliptical type. Both types have slits between some of their elements, as has G. protohuxleyi (see the foregoing discussion), but this may be the result of an environmental factor or it may be morphological convergence.

P. lacunosa s.l. occurs in both holes in the lowermost Pleistocene. It is never abundant, and disappears at 548-7-6 and 549A-3-2. The age of this last occurrence is well documented in the literature (Thierstein et al., 1977). Gartner (1977) noted a "global synchroneity of the $P$. lacunosa extinction," and correlated this phenomenon with isotopic records at various latitudes; the event occurred in the middle of Stage 12, that is, about 0.46 m.y. ago.

\section{The Helicopontosphaera Group}

Helicosphaera or Helicopontosphaera?-this question is often asked. Jafar and Martini (1975) have dealt with it at length and opted for the "relegation" of Helicopontosphaera. In 1977, Hay kept this term because "the type species of Helicosphaera, Coccolithus carterae,... was a species closely related to Coccolithus pelagicus, and the forms that Kamptner had considered as belonging to Helicosphaera carteri were very different from the original figure." I have the same opinion as Hay, and I prefer to use the term Helicopontosphaera.

In the Leg 80 Pleistocene sediments, this genus comprises three species. They succeed each other in time throughout the Quaternary at Hole 548.

$H$. sellii is a small species (length $=8.5 \mu \mathrm{m}$ ) with a restricted flange and two oblique, medium-size holes. Since Gartner's work in 1977, it is considered a marker of the lower Pleistocene. It disappeared $1.22 \mathrm{~m} . \mathrm{y}$. ago (Hole 548: Section 11-6; absent in Hole 549A).

$H$. gr. kamptneri is medium in size (length $=10 \mu \mathrm{m}$ ), with a round, regular flange and two small central slits. This group includes specimens such as $H$. wallichi, which according to Haq (1973) is similar in morphology to $H$. kamptneri. $H$. wallichi, however, has a smaller flange than $H$. kamptneri. $H$. gr. kamptneri is present at the two sites between $548-7-1$ and the top of the Hole 548 and between 549A-3-3 and the top of Hole 549A.

$H$. neogranulata is medium to large (length $=13 \mu \mathrm{m}$ ); its flange becomes wider at its termination and shows complete extinction of its largest part in cross-polarized light. There is a wide longitudinal slit enclosing a granular texture, as seen with the light microscope. It occurs in the middle Pleistocene (548-11-6 to 548-7-1 and below 549A-3-3), from the extinction of $H$. sellii to the place where $H$. gr. kamptneri reappears after being absent from the lowest samples of the Quaternary sections. Gartner remarked the presence of this species "sporadically in the middle and lower Pleistocene." The range can be defined more precisely, however: the last occurrence is above the extinction of $P$. lacunosa. A tentative and approximate age of this event will be given in the section on datum levels.

\section{The Cyclococcolithina Group}

Two species, leptopora and macintyrei, are placed within the genus Cyclococcolithina in Leg 80 samples. The choice of the genus was not easy. Loeblich and Tappan $(1970 b, 1971)$ placed macintyrei in the genus Cyclococcolithus; but, before that (1970a), they considered this genus as illegitimate, writing that it is a junior synonym of Calcidiscus (1969). Hay (1977) considers Cyclococcolithus as illegitimate, and Calcidiscus as a subjective senior synonym of Cyclococcolithina, because the type species Calcidiscus quadriforatus is a fragment of Cyclococcolithina. Before Hay, Wilcoxon (1970) and Loeblich and Tappan (1971) placed leptopora under this 


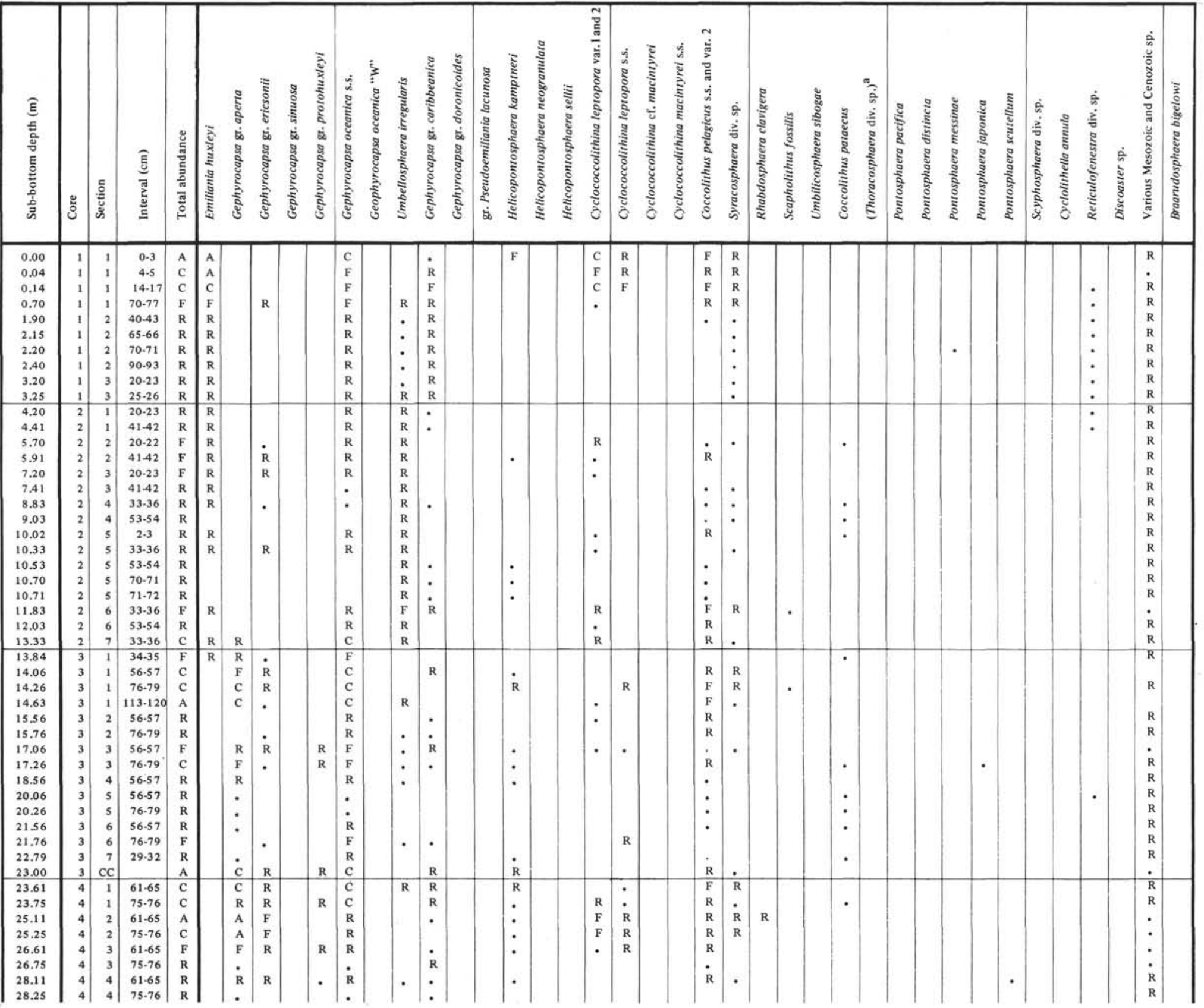




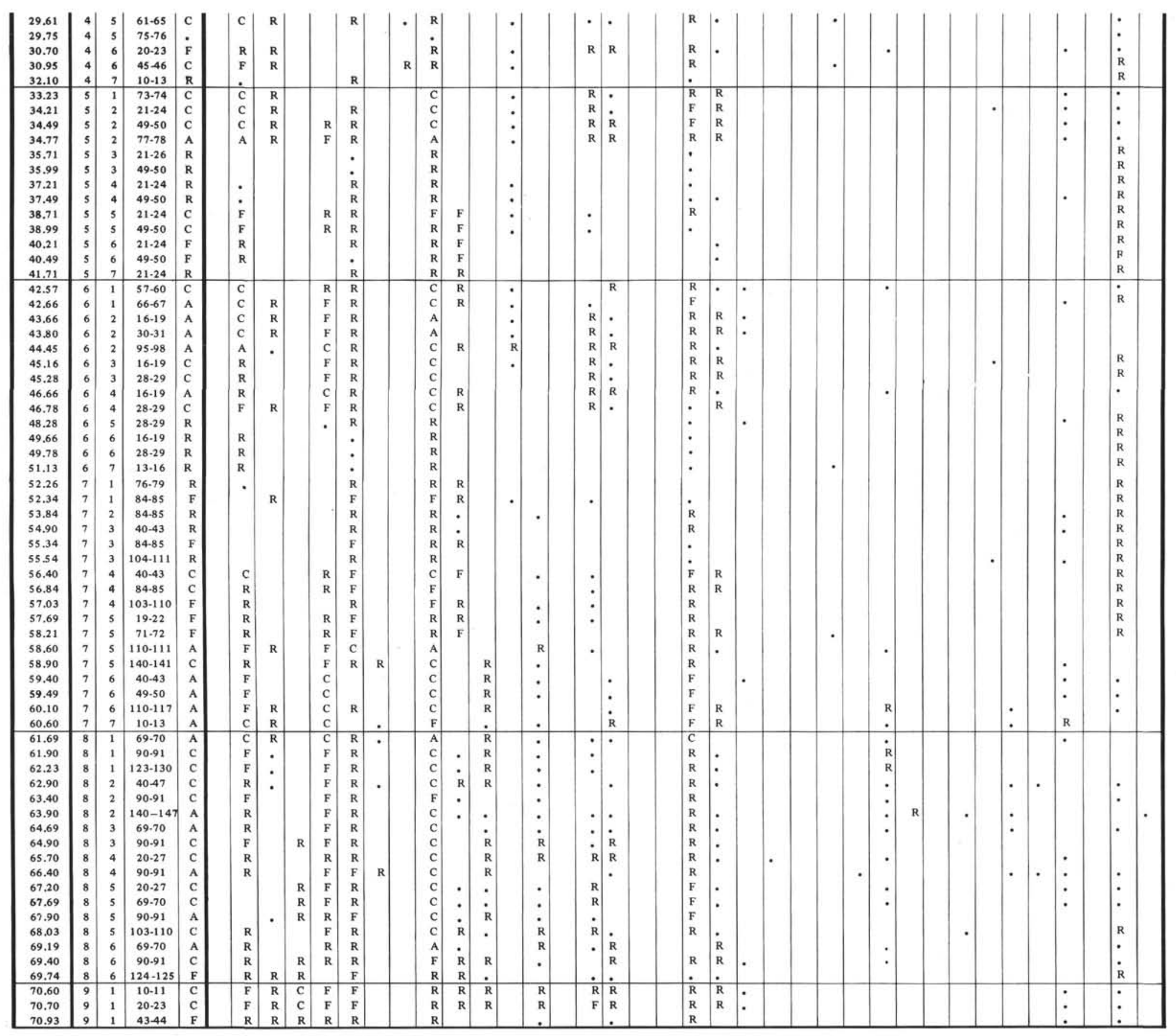




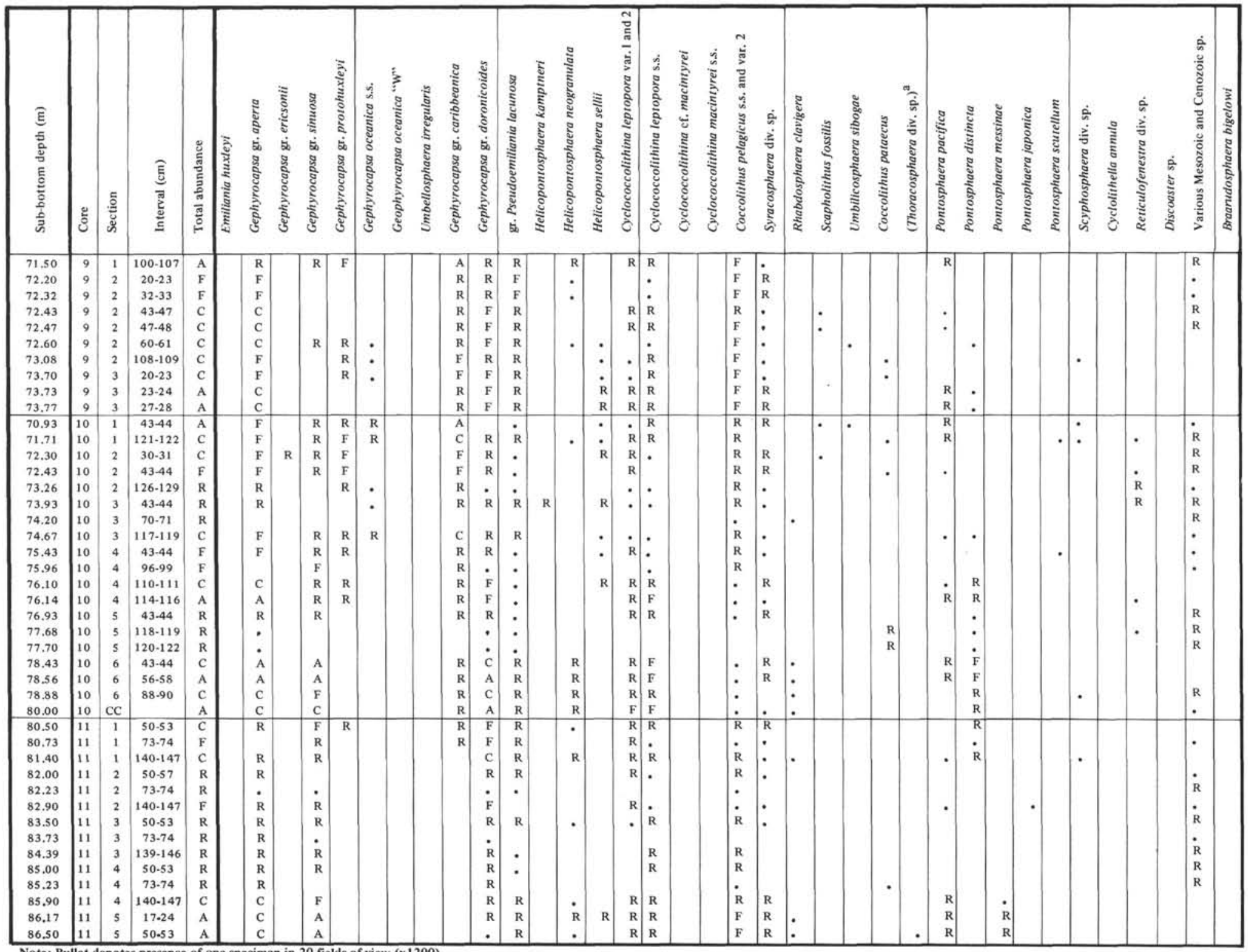

Although this genus is assumed to belong to Dinophyceae, it has been placed among nannofossils, because they are usually observed on the same slides. 
generic name. I agree with this denomination of Cyclococcolithina.

This genus is present throughout the Pleistocene sections of Leg 80. It is sporadic, but sometimes its coccoliths are abundant, and vary in size and number of elements. Within this group, various authors described different morphotypes: McIntyre et al. (1967) and McIntyre and Bé (1967) have distinguished three variants (A, B, and $\mathrm{C}$ ) within the $C$. leptopora species, on the basis of diameter and number of elements.

The size of many Cyclococcolithina coccoliths was measured on specimens from Holes 548 and 549A, and their elements were counted on SEM micrographs. The boundaries among morphotypes are not as sharp as those found in the McIntyre study. I found five main morphotypes in the samples from Leg 80 ; they are described in Table 4.

\section{The Coccolithus pelagicus Group}

C. pelagicus s.s. occurs throughout the Pleistocene of Holes 548 and 549A, and is abundant at some levels (mostly below 548-7-5). Some variants can be distinguished:

C. pelagicus var. 1 is rare in most of the samples but abundant whenever $C$. pelagicus s.s. is less abundant. The coccoliths of this variant are small (less than $7 \mu \mathrm{m}$ in length) and very bright under cross-polarized light. This variant is so rare that I could not observe it in the SEM, but it could be useful for further ecological study.

C. pelagicus var. 2 has a short range between 548-154 and 548-14-2. It resembles the s.s. species, but is about one third larger.

The presence of var. 2 in the same samples as Cycloccolithina cf. macintyrei may indicate a stratigraphic importance.

\section{CONVENTIONAL AND ADDITIONAL NANNOFOSSIL DATUMS OF LEG 80}

Some datum levels of Quaternary nannofossils are well documented. The first and last appearances of $E$. huxleyi, P. lacunosa, and C. macintyrei have been dated worldwide. These species may be considered as conventional marker species.

A second group of datum levels is described by more than one author for different oceans and/or at various latitudes. These datum levels may get an age assignment by comparison with paleomagnetic events or isotopic stages. Sometimes an extrapolation of sediment accumulation rates may assist in dating. These datums are Helicopontosphaera sellii, the "small Gephyrocapsa," Gephyrocapsa oceanica s.s. (Gartner, 1977), Umbellosphaera irregularis (Gartner and Emiliani, 1976), G. caribbeanica (Thierstein et al., 1977), and G. doronicoides (Bukry, 1970, Perch-Nielsen, 1972). Although they are used occasionally, they are not considered to be conventional markers, for they cannot be used worldwide.

The study of nannofossils from Holes 548 and 549A (Fig. 4) confirms the dates of the conventional datums, and may provide information on some additional markers. Among these new markers, there are the lowest and highest occurrences of species and variants of species, and acmes are also used. These markers do not correspond "to the concept of datum level as commonly perceived" (Gartner, 1977). But several authors (e.g., Gartner, Bukry) consider the acme as useful in stratigraphy. Hole 548 is used as a reference section. From the earliest to the late Quaternary, the datum levels are as follows:

- $\mathrm{LO} / \mathrm{HO}^{3}$ of Coccolithus pelagicus var. 2

- LO/HO of Gephyrocapsa protohuxleyi (more data of environmental influences on this taxon are needed to evaluate its usefulness as a marker).

- Acme of G. oceanica s.s.

- $\mathrm{LO} / \mathrm{HO} / \mathrm{acme}$ of the five variants of $G$. doronicoides

- $\mathrm{HO}$ of G. producta

- LO/HO/acme of G. sinuosa

${ }^{3} \mathrm{HO}=$ highest occurrence; LO $=$ lowest occurrence.

Table 4. The Cyclococcolithina group.

\begin{tabular}{|c|c|c|c|c|c|}
\hline & $\begin{array}{l}\text { Diameter } \\
\qquad(\mu \mathrm{m})\end{array}$ & $\begin{array}{l}\text { Number of } \\
\text { elements }\end{array}$ & $\begin{array}{l}\text { Central } \\
\text { area }\end{array}$ & $\begin{array}{l}\text { Correspondence } \\
\text { to previously } \\
\text { described types }\end{array}$ & $\begin{array}{c}\text { Occurrence } \\
\text { in Holes } \\
548 \text { and } 549 \mathrm{~A}\end{array}$ \\
\hline C. leptopora var. 1 & $5-7$ & $19-28$ & Closed & $\begin{array}{l}\text { C. leptopora var. C and } \\
\text { transition to var. B } \\
\text { (Mcintyre et al., 1967). }\end{array}$ & Throughout the Pleistocene \\
\hline C. leptopora var. 2 & $4-5$ & $15-19$ & Closed & $\begin{array}{l}\text { Most of the } C \text {. leptopora } \\
\text { var. } C \text { (McIntyre et al., } \\
\text { 1967) }\end{array}$ & $\begin{array}{l}\text { Between } 548-11-2 \text { and } 548- \\
7-6\end{array}$ \\
\hline C. leptopora s.s. & $7.5-11.3$ & $27-38$ & Closed & $\begin{array}{l}\text { Original diagnosis of } \\
\text { Murray and Blackman } \\
\text { (1898) } \\
\text { C. leptopora s.s. (Čepek } \\
\text { and Wind, 1979) }\end{array}$ & $\begin{array}{l}\text { Throughout the Pleistocene, } \\
\text { mostly between } 548-14- \\
1 \text { and } 548-10-6 \text {, and } \\
\text { below 549A-3-6 }\end{array}$ \\
\hline C. cf. macintyrei & $7.5-10.5$ & $29-40$ & $\begin{array}{l}\text { Clearly } \\
\text { open (hole } \\
2 \mu \mathrm{m})\end{array}$ & $\begin{array}{l}\text { Transition between } C \text {. } \\
\text { leptopora var. A and B } \\
\text { (McIntyre et al, }, 1967) \\
\text { C. cf. macintyrei (Cepek } \\
\text { and Wind, 1979) }\end{array}$ & $\begin{array}{l}\text { Between } 548-15-4 \text { and } 548 \text { - } \\
\qquad 14-1 \\
\text { Absent from Hole 549A }\end{array}$ \\
\hline C. macintyrei s.s. & $9.5-16$ & $35-46$ & $\begin{array}{l}\text { Open } \\
\text { (hole of } \\
\text { about } 3 \mu \mathrm{m} \text { ) }\end{array}$ & $\begin{array}{l}\text { C. leptopora var. A (Mcln- } \\
\text { tyre et al., 1967, and } \\
\text { McIntyre and Bé, 1967) }\end{array}$ & $\begin{array}{l}\mathrm{HO} \text { in Hole } 548 \text { at Sec. } 15-1 \\
\text { Absent from Hole } 549 \mathrm{~A}\end{array}$ \\
\hline
\end{tabular}




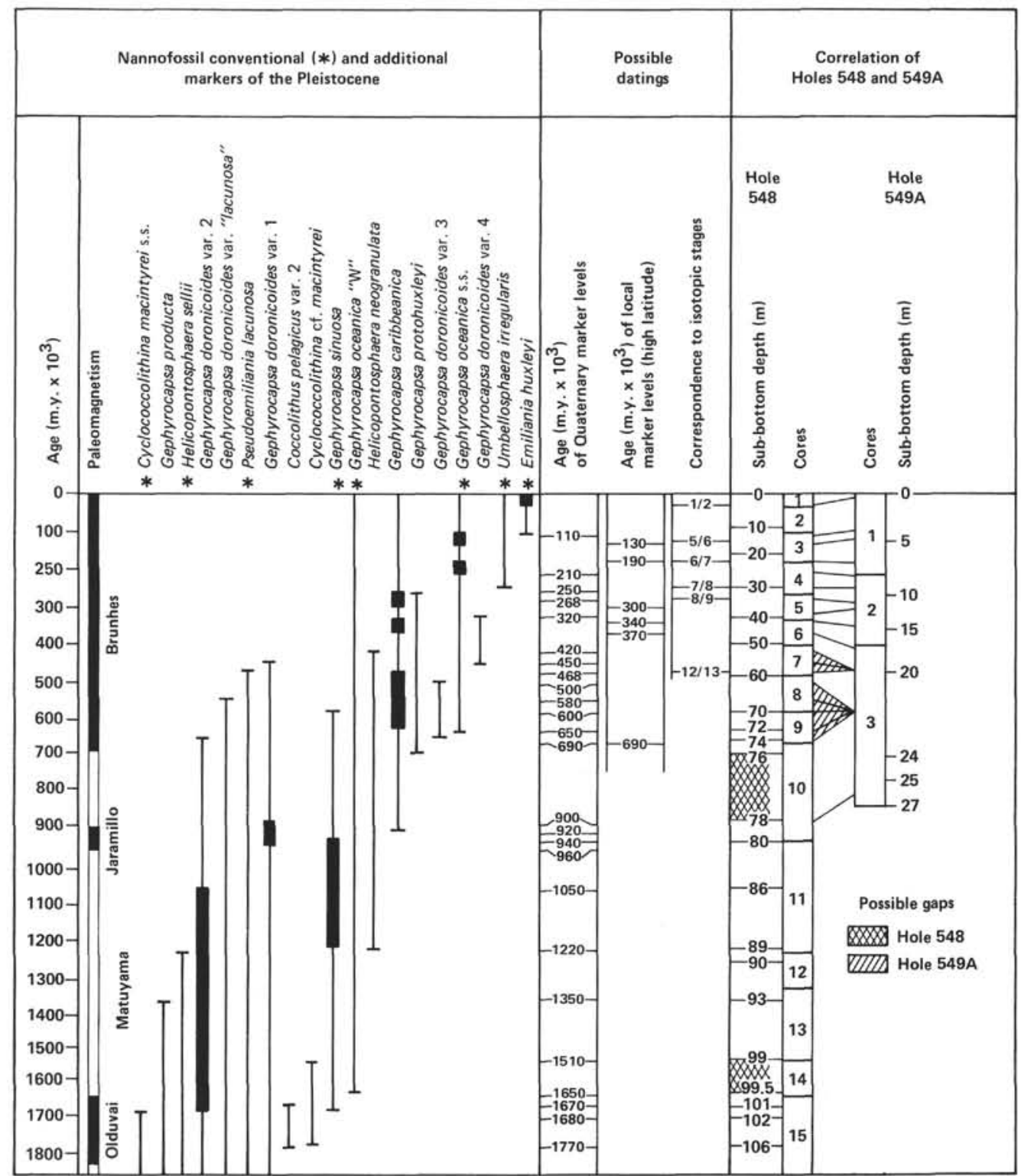

Figure 4. Tentative high-latitude biostratigraphy of the Pleistocene, based on nannofossils. Correlation of Holes 548 and 549A.

- LO and beginning of acme of G. caribbeanica

- HO of Helicopontosphaera neogranulata

- Acme of Emiliania huxleyi, if it is possible to recognize this species.

\section{THE AGES OF DATUMS}

Conventional datums and paleomagnetic events have been precisely dated; with their positions in the sections of Holes 548 and 549A it is possible to evaluate sediment accumulation rates (Figs. 5 and 6) and to give a tentative age to nannofossil datums and other stratigraphic features:

- LO of Gephyrocapsa oceanica: about 1.6 m.y. by extrapolation of Gartner's study (1977)

- HO of Cyclococcolithina macintyrei s.1.: 1.51 m.y.
- HO of Helicopontosphaera sellii: 1.22 m.y.

- Bottom and top of acme of G. sinuosa (here they are considered as the "small Gephyrocapsa" of Gartner [1977]): 1.22 and 0.92 m.y.

- Top of acme of $G$. doronicoides s.s. (= var. 1): about $0.8 \mathrm{~m} . \mathrm{y}$.

- HO of Pseudoemiliania lacunosa: middle of isotopic Stage 12 , about 0.46 m.y.

- Last peak of G. caribbeanica: isotopic Stage 9, about 0.268 m.y.

- LO of Umbellosphaera irregularis: isotopic Stages 7 (188-244 m.y.) or 8 (244-279 m.y.) (after Morley and Hays, 1981).

Then, new markers can be added on the sediment accumulation curves according to their sub-bottom depth in Hole 548 (Fig. 5), and an approximate age of these new markers can be obtained. 
Most of the additional markers belong to $G$. doronicoides and its variants; they provide ages for a period (early Pleistocene) poor in conventional events:

- Beginning of acme of var. 2: 1.67 m.y.

- End of acme of var. 2 and beginning of var. "lacunosa": 1.05 m.y.

- LO and HO of var. 3: 0.69 and 0.5 m.y.

- LO and HO of var. 4: 0.45 and 0.32 m.y.

Also, in the early Quaternary:

- HO of G. producta: 1.35 m.y.

- LO of G. sinuosa and HO of C. macintyrei: 1.68 m.y.

- LO and HO of C. pelagicus var. 2: 1.77 and 1.67 m.y.

In the Brunhes chron:

- Beginning of acme of $G$. protohuxleyi and of $G$. caribbeanica and LO of G. oceanica s.s. at the same time, $0.65 \mathrm{~m}$.y. ago. G. caribbeanica shows three maxima during this acme (see Fig. 4), and G. oceanica s.s. has two maxima during its acme; these fluctuations are due to glaciation.
- HO of G. sinuosa, about 0.6 m.y.

- All the small Gephyrocapsa (mostly G. aperta) disappeared about 0.11 m.y. ago, but this event occurred later at lower latitudes (Pujos-Lamy, 1976). These taxa are influenced, more than other species, by environmental factors, and cannot be considered as good markers.

- HO of Helicopontosphaera neogranulata: 0.42 m.y.; at the same time, $H$. gr. kamptneri, from the early and middle Pleistocene, reappears.

The LO of Emiliania huxleyi is not a useful datum, since the species is too rare to be observed with a light microscope. However, it has an acme which began about 0.10 to 0.15 m.y. ago ( $=$ isotopic Stage $1 / 2$ boundary) and continues till now.

\section{SEDIMENT ACCUMULATION RATES}

Sediment acumulation rates in Holes 548 and 549A are plotted in Figures 5 and 6. This rate shows a similar history in the two sections: in the early Pleistocene to 0.69 m.y. ago (Brunhes/Matuyama boundary) it was low, $10 \mathrm{~m} / \mathrm{m} . \mathrm{y}$. (Unit 1). Between 0.69 and 0.47 m.y. ago

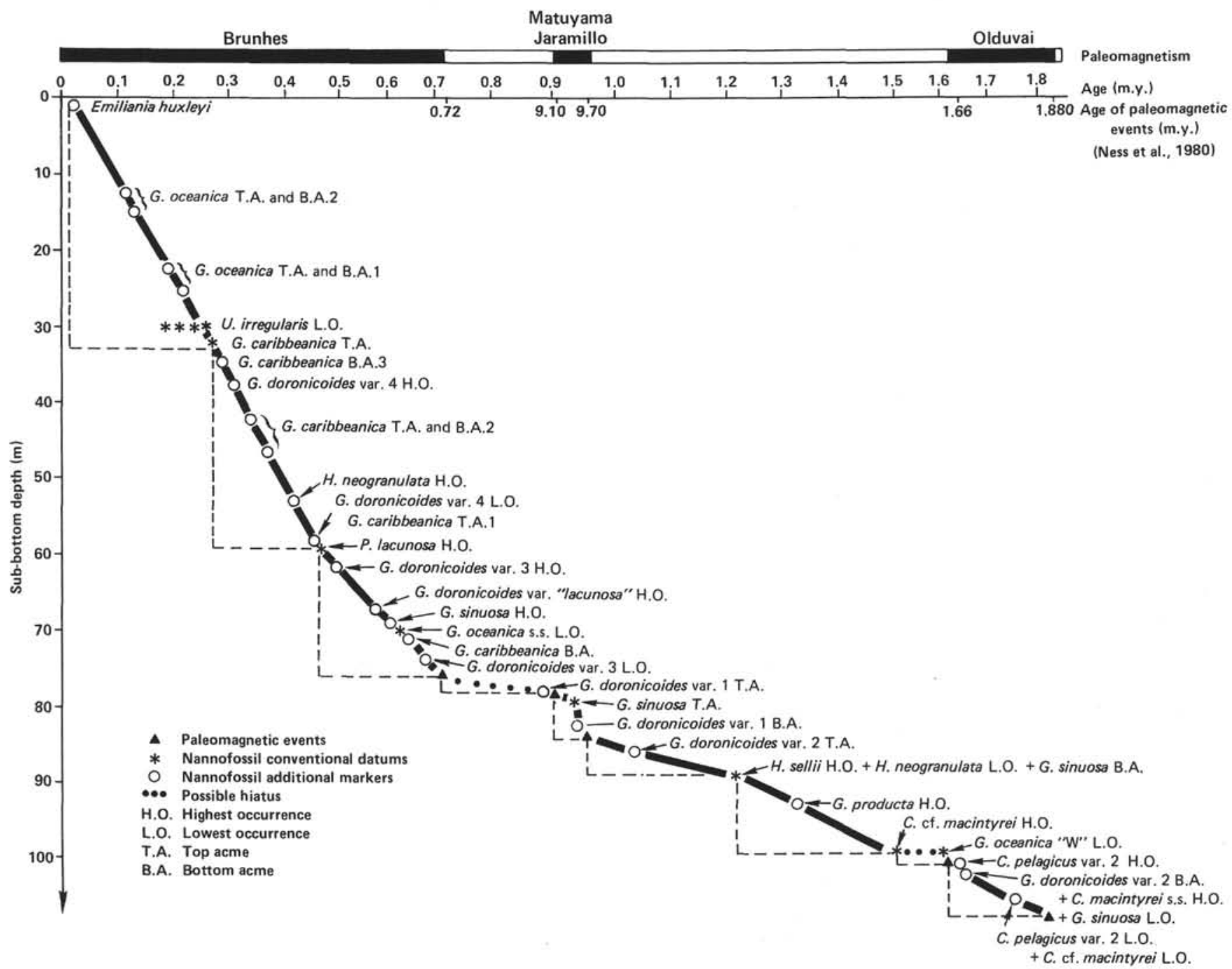

Figure 5. Quaternary sediment accumulation rates, nannofossils, and paleomagnetism, Hole 548. 


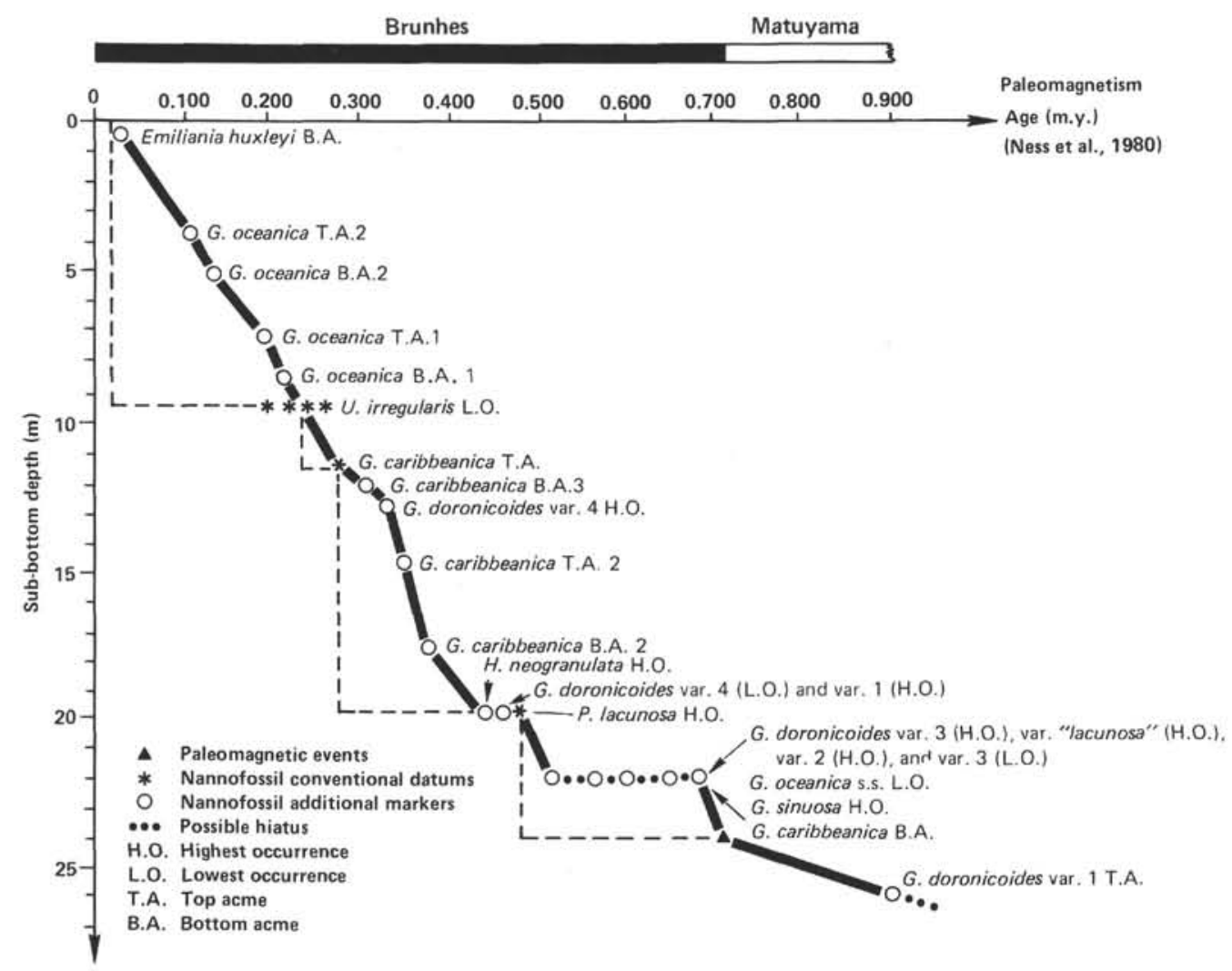

Figure 6. Quaternary sediment accumulation rates, nannofossils, and paleomagnetism, Hole 549A.

(highest occurrence of $P$. lacunosa) it was medium: 37.5 and $45 \mathrm{~m} / \mathrm{m}$.y. (Unit 2). Since $0.47 \mathrm{~m} . \mathrm{y}$. ago it is high: 125 and $65 \mathrm{~m} / \mathrm{m} . \mathrm{y}$. (Unit 3). Each of these three units corresponds to a special environment:

1. Unit 1 (important in Hole 548): This unit has a rapid alternation of intervals with abundant coccoliths and intervals with rare coccoliths. Micropaleontological events are very closely spaced in the sediment record. Sediment accumulation was continuous in Hole 548, except between 1.5 and 1.6 m.y. ago $(100 \mathrm{~m})$ and between 0.88 and $0.69 \mathrm{~m} . \mathrm{y}$. ago $(78-75 \mathrm{~m})$. The first of these levels represents a hiatus and the section a zone of "drilling disturbance." Most of the second gap (between top of Jaramillo and Brunhes/Matuyama boundary) is fortunately present in Hole 549A, the bottom of which can be dated at about $0.87 \mathrm{~m}$.y. ago.

2. Unit 2 shows few changes in the total nannofossil abundance, which is almost always high: during the middle Pleistocene, the influence of glaciation on calcareous phytoplankton may have been weak. Sediment accumulation seems to have been continuous at Site 548 . In Hole 549A, a hiatus occurs at $22 \mathrm{~m}(0.65-0.5 \mathrm{~m} . \mathrm{y}$.), and a short gap occurs at $20 \mathrm{~m}(0.47-0.42 \mathrm{~m} . \mathrm{y}$.). According to the preliminary data at this level there is a "sandy, calcareous, marly ooze," which may be shallower, reworked sediment, or may represent winnowing.

3. Unit 3 shows strong variations in nannofossils at the two holes. It is an alternation of abundant populations and almost barren zones. Such phenomena can be explained by a succession of warm and glacial periods (McIntyre et al., 1972); the effect of glaciation on the calcareous phytoplankton is evident at the Goban Spur, dating from $0.47 \mathrm{~m} . \mathrm{y}$. ago to the present.

\section{GLACIATION AND CALCAREOUS PHYTOPLANKTON}

For a better assessment of climatic effects on nannofossils, we must study cores that show insignificant reworking and continuous high sediment accumulation rates (e.g., upper Pleistocene, Leg 80). Unfortunately, most of the lower to middle Pleistocene is not present in the section from Hole 549A. The lower to middle Pleistocene is represented by irregular deposits in Hole 548, so this study will concentrate on the period between 0.5 m.y. ago and the present (Fig. 7).

Ruddiman and McIntyre (1976) correlated the total nannofossil abundance with the influence of glaciation: barren zones are correlated with glacial periods "when the overlying surface waters were devoid of coccoliths.... The productivity variations are the primary cause of coccolith barren zones in the Atlantic Ocean north of latitude $40^{\circ} \mathrm{N}$." We can observe the major climatic cycles, which these authors described on the basis of planktonic fauna and oxygen-isotope studies, as they are reflected in nannofossil abundances.

For Leg 80, Vergnaud Grazzini (this vol.) measured and calculated $\delta^{18} \mathrm{O}$ and $\delta^{13} \mathrm{C}$ in the shells of foraminifers. She studied the upper Pleistocene in Hole 549A material only. A correlation between the isotopic curve and nannofossil total abundance is evident (Fig. 7), but there is a small diachronism at the boundary between stages. These differences are probably effects of the sam- 


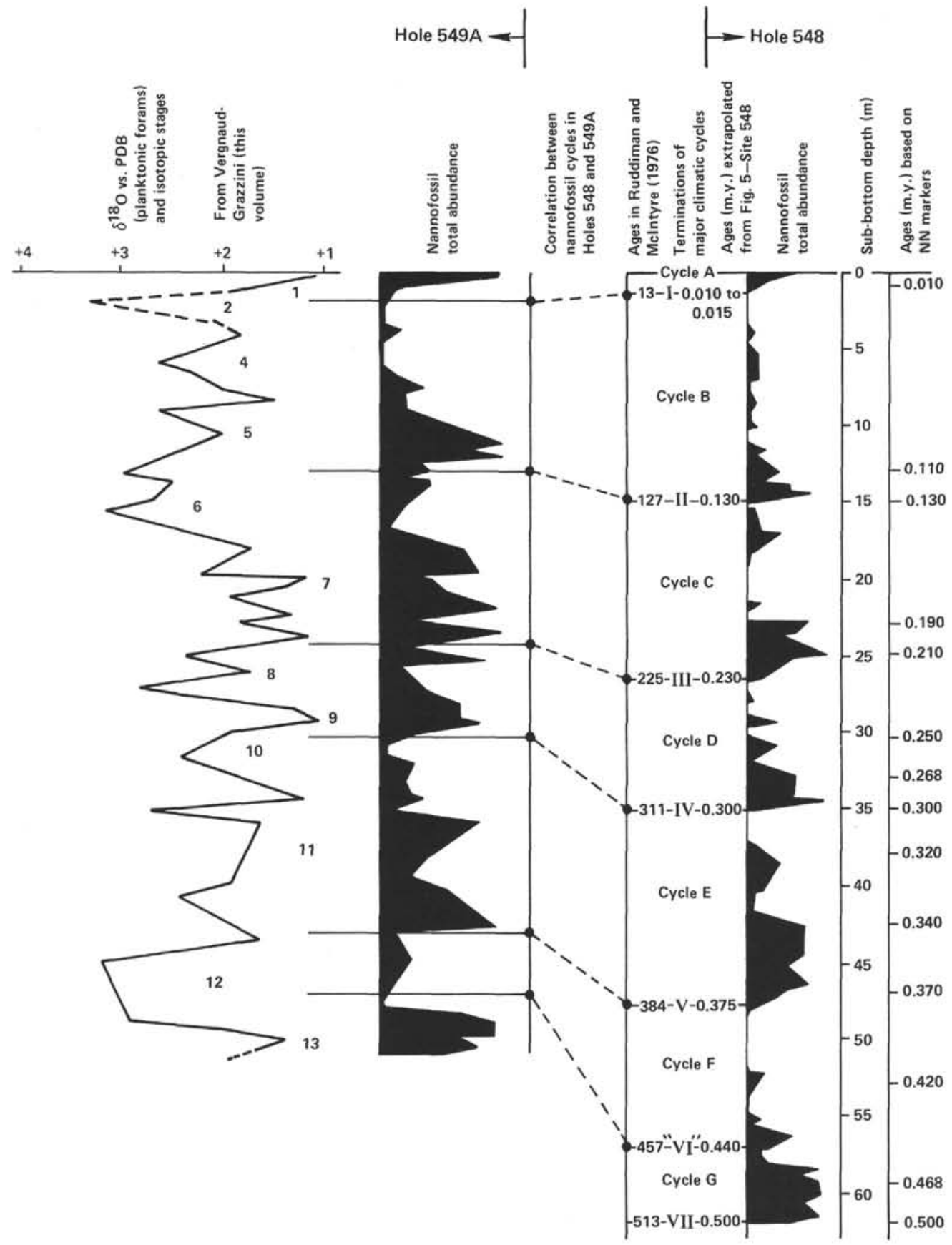

Figure 7. Tentative climatic interpretation of nannofossil total abundance at Holes 548 and 549A, for the last 0.5 m.y.

pling (for nannofossils the size of the sample is much smaller) or of the different responses of the phytoplankton and foraminifers. In that case it is easier to use the method of "terminations" of major climatic cycles: they can be placed on the curve of the nannofossil total abundance and dated by extrapolation of the ages of markers (from Figs. 2 and 3). Such ages resemble closely the termination ages of Ruddiman and McIntyre (1976). This is evidence of the strong influence of climatic events on calcareous phytoplankton.

\section{ACKNOWLEDGMENTS}

I thank K. Perch-Nielsen, École Polytechnique Fédérale, Zurich, and S. Gartner, Texas A \& M University, College Station, Texas, who reviewed the manuscript and offered valuable suggestions. I would like also to thank P. C. de Graciansky, École Nationale Supérieure des Mines, Paris, a Co-Chief for Leg 80, for making samples available for study, and C. Müller, who provided Quaternary samples. Special thanks to E. Thomas, Lamont-Doherty Geological Observatory, Palisades, New York, who was kind enough to rewrite my French English into real English! SEM photographs were taken at the Centre de Microscopie Electronique, Talence; I am especially grateful to M. Leblanc for her kind assistance. 


\section{REFERENCES}

Black, M., and Barnes, B., 1959. The structure of coccoliths from the English chalk. Geol. Mag., 96(5):321-328.

Bréhéret, J. G., 1977. Les coccolithes du Pleistocène supérieur et de l'Holocène de 2 carottes profondes de l'Atlantique nord. Systématique, biostratigraphie, paléoclimatologie [Thèse]. Université de Nantes.

,1978. Formes nouvelles quaternaires et actuelles de la famille des Gephyrocapsaceae (Coccolithophoridés). Compt. Rend. Acad. Sci. Paris, D, 287:447-449.

Bukry, D., 1970. Coccolith are determinations, Leg 4, Deep Sea Drilling Project. In Bader, R. G., Gerard, R. D., et al., Init. Repts. $D S D P, 4$ : Washington (U.S. Govt. Printing Office), 123-131. 1971. Cenozoic calcareous nannofossils from the Pacific Ocean. Trans. San Diego Soc. Nat. Hist., 16:303-328.

1973. Coccolith stratigraphy, eastern equatorial Pacific, Leg 16, Deep Sea Drilling Project. In van Andel, T. H., Heath, G. R., et al., Init. Repts. DSDP, 16: Washington (U.S. Govt. Printing Office), 653-711.

Čepek, P., and Wind, F. H., 1979. Neogene and Quaternary calcareous nannoplankton from DSDP Site 397 (northwest African margin). In von Rad, U., Ryan, W. B. F., et al., Init. Repts. DSDP, 47, Pt. 1: Washington (U.S. Govt. Printing Office), 289-316.

Emiliani, C., 1955. Pleistocene temperatures. J. Geol., 63:538-578. 1966. Paleotemperature analysis of Caribbean Cores $P$ 6301-8 and P 6301-9 and a generalized temperature curve for the last 425,000 years. J. Geol., 74:109-126.

Gartner, S., 1977. Calcareous nannofossil biostratigraphy and revised zonation of the Pleistocene. Mar. Micropaleontol, 2:1-25.

Gartner, S., and Emiliani, C., 1976. Nannofossil biostratigraphy and climatic stages of Pleistocene Brunhes epoch. Am. Assoc. Petrol. Geol. Bull., 60:1562-1564.

Haq, B. U., 1973. Evolutionary trends in the Cenozoic coccolithophore genus Helicopontosphaera. Micropaleontology, 19:32-52.

Hay, W. W., 1977. Calcareous nannofossils. In Ramsay, A. T. S. (Ed.), Oceanic Micropaleontology (Vol. 2): New York (Academic Press), 1055-1200.

Hay, W. W., and Beaudry, F. M., 1973. Calcareous nannofossils, Leg 15, Deep Sea Drilling Project. In Edgar, N. T., Saunders, J. B., et al., Init. Repts. DSDP, 15: Washington (U.S. Govt. Printing Office), 625-683.

Jafar, S. A., and Martini, E., 1975. On the validity of the calcareous nannoplankton genus Helicosphaera. Senckenbergiana Lethaea, 56: 381-397.

Loeblich, A. R., Jr., and Tappan, H., 1969. Annotated index and bibliography of the calcareous nannoplankton III. J. Paleontol., 43: 568-588.

1970a. Annotated index and bibliography of the calcareous nannoplankton IV. J. Paleontol., 44:558-574.

, 1970b. Annotated index and bibliography of the calcareous nannoplankton V. Phycologia, 9:157-174.

1971. Annotated index and bibliography of the calcareous nannoplankton VI. Phycologia, 10:309-339.

McIntyre, A., 1970. Gephyrocapsa protohuxleyi sp. n., a possible phyletic link and index fossil for the Pleistocene. Deep Sea Res., 17:187-190.
McIntyre, A., and Bé, A. W. H., 1967. Modern Coccolithophoridae of the Atlantic Ocean. I. Placoliths and cyrtoliths. Deep Sea Res., 14:561-597.

McIntyre, A., Bé, A. W. H., and Preikstas R., 1967. Coccoliths and the Pliocene-Pleistocene boundary. In Sears, M. (Ed.), Progress in Oceanography (Vol. 4): Oxford (Pergamon Press), 3-25.

McIntyre, A., Ruddiman, W. F., and Jantzen, R., 1972. Southward penetrations of the North Atlantic polar front: faunal and floral evidence of large-scale surface water mass movements over the last 225,000 years. Deep Sea Res., 19:61-77.

Martini, E., and Worsley, T., 1970. Standard Neogene calcareous nannoplankton zonation. Nature, 225:289-290.

Morley, J. J., and Hays, J. D., 1981. Towards a high resolution, global, deep-sea chronology for the last 750,000 years. Earth Planet. Sci. Lett., 53:279-295.

Murray, G., and Blackman, V. H., 1898. On the nature of the coccospheres and rhabdospheres. Philos. Trans. Soc. London, 190: 427-441.

Ness, G., Levi, S., and Couch, R., 1980. Marine magnetic anomaly timescales for the Cenozoic and Late Cretaceous: a precis, critique, and synthesis. Rev. Geophys. Space Phys., 18:753-770.

Okada, H., and Bukry, D., 1980. Supplementary modification and introduction of code-numbers to the low-latitude coccolith biostratigraphic zonation (Bukry, 1973; 1975). Mar. Micropaleontol., 5: 321-326.

Perch-Nielsen, K., 1972. Remarks on Late Cretaceous to Pleistocene coccoliths from the North Atlantic. In Laughton, A. S., Berggren, W. A., et al., Init. Repts. DSDP, 12: Washington (U.S. Govt. Printing Office), 1003-1069.

Pujos-Lamy, A., 1976. Emiliania et Gephyrocapsa (nannoplancton calcaire): biométrie et intérêt biostratigraphique dans le Pleistocène supérieur marin des Açores. Rev. Espan. Micropaleontol, 9: 69-84.

1977. Essai d'établissement d'une biostratigraphie du nannoplancton calcaire dans le Pleistocène de l'Atlantique nord-oriental. Boreas, 6:323-331.

Ruddiman, W. F., and McIntyre, A., 1976. Northeast Atlantic paleoclimatic changes over the past 600,000 years. Mem. Geol. Soc. Am., 145:111-146.

Samtleben, C., 1978. Pliocene-Pleistocene coccolith assemblages from the Sierra Leone Rise - Site 366, Leg 41. In Lancelot, Y., Seibold, E., et al., Init. Repts. DSDP, 41: Washington (U.S. Govt. Printing Office), 913-921.

Shackleton, N. J., and Opdyke, N. D., 1973. Oxygen isotope and paleomagnetic stratigraphy of equatorial Pacific Core V.28-238: oxygen isotope temperatures and ice volumes on a $10^{3}$ year and $10^{6}$ year scale. Quat. Res., 3:39-55.

Thierstein, H. R., Geitzenauer, K. R., Molfino, B., and Shackleton, N. J., 1977. Global synchroneity of late Quaternary coccolith datum levels: validation by oxygen isotopes. Geology, 5:400-404.

Wilcoxon, J. A., 1970. Cyclococcolithina Wilcoxon nom. nov. (nom. subst. pro Cyclococcolithus Kamptner, 1954). Tulane Studies Geol. Paleontol., 8:82-83.

Winter, A., Reiss, Z., and Luz, B., 1978. Living Gephyrocapsa protohuxleyi McIntyre in the Gulf of Elat ('Aqaba). Mar. Micropaleontol., 3:295-298.

Date of Initial Receipt: March 4, 1983

Date of Acceptance: October 21, 1983 

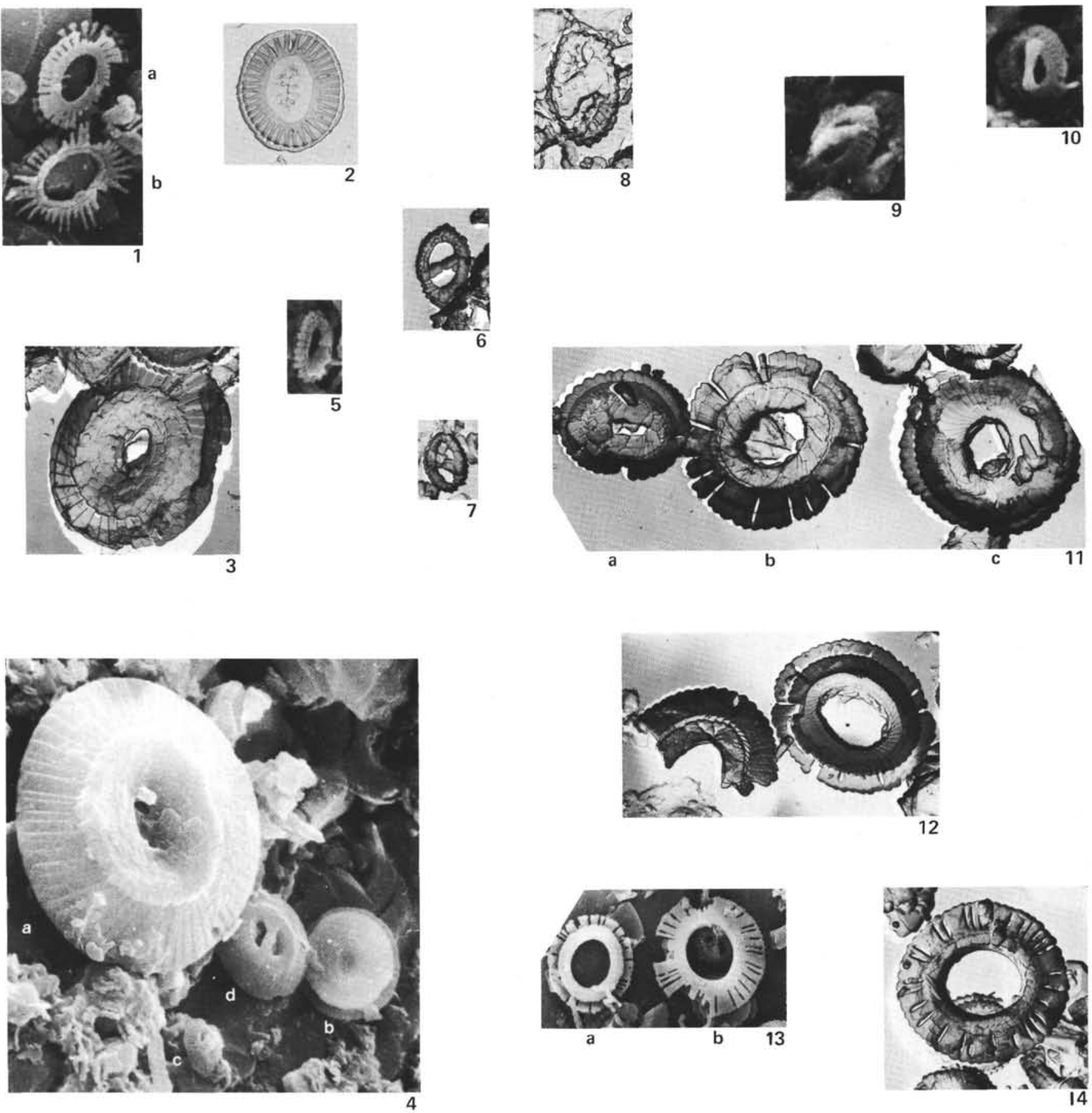

14

Plate 1. (TEM = transmission electron microscope $\mathrm{SEM}=$ scanning electron microscope.) 1-2. Emiliania huxleyi, $\times 6000,(1)$ Sample 548-1-1, 0-3 cm, SEM, a = warm form, $\mathrm{b}=$ cold form, (2) Sample 549A-1-1, 1-4 cm, TEM, cold form. 3-4. Coccolithus pelagicus, $\times 3000$, (3) C. pelagicus s.s., Sample 548-14,CC, TEM, (4) C. pelagicus var. 2, with Cyclococcolithina leptopora var. 1, Gephyrocapsa protohuxleyi, and G. doronicoides var. 1, Sample 548-11-5, 17-24 cm, SEM. 5-7. Gephyrocapsa aperta, $(5,7)$ G. aperta var. $1(5$, Sample 549A-3-5, 80-85 cm, $\times 6000$, SEM; 7, Sample 548-13-4, 35-38 cm, $\times 4500$, TEM), (6) G. aperta var. 2, Sample 548-14,CC, $\times 4500$, TEM. 8. Gephyrocapsa sinuosa, Sample 548-11-6, 5-8 cm, $\times 6000$, TEM. 9-10. Gephyrocapsa protohuxleyi, $\times 3000$, SEM, (9) Sample 548-4-2, 61-65 cm, (10) Sample 54810-4, 114-116 cm. 11. a Gephyrocapsa producta, b Pseudoemiliania lacunosa elliptical type, and c G. doronicoides var. 1, Sample 548-13-4, $35-38 \mathrm{~cm}, \times 4500$, TEM. 12-14. Pseudoemiliania lacunosa, (12-13) elliptical types, Sample 549A-3-6, 80-84 cm (12, $\times 4500$, TEM; 13a proxi$\mathrm{mal}$ and $\mathrm{b}$ distal sides, $\times 3000, \mathrm{SEM}),(14)$ round type, Sample $548-13-6,80-81 \mathrm{~cm}, \times 4500$, TEM. 

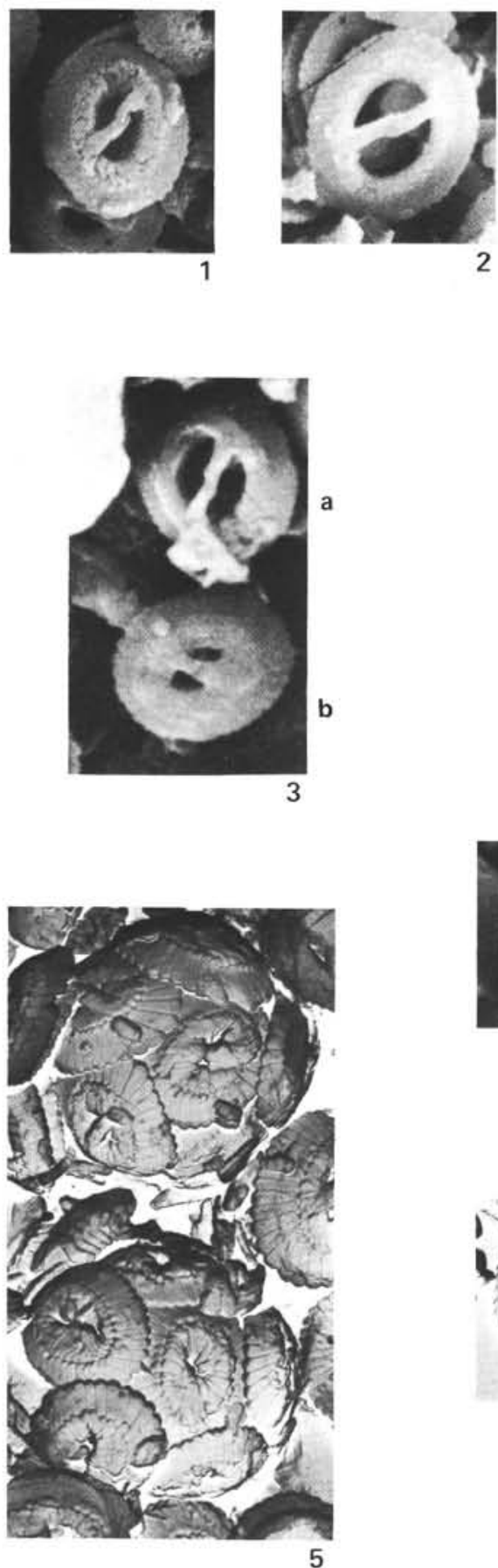
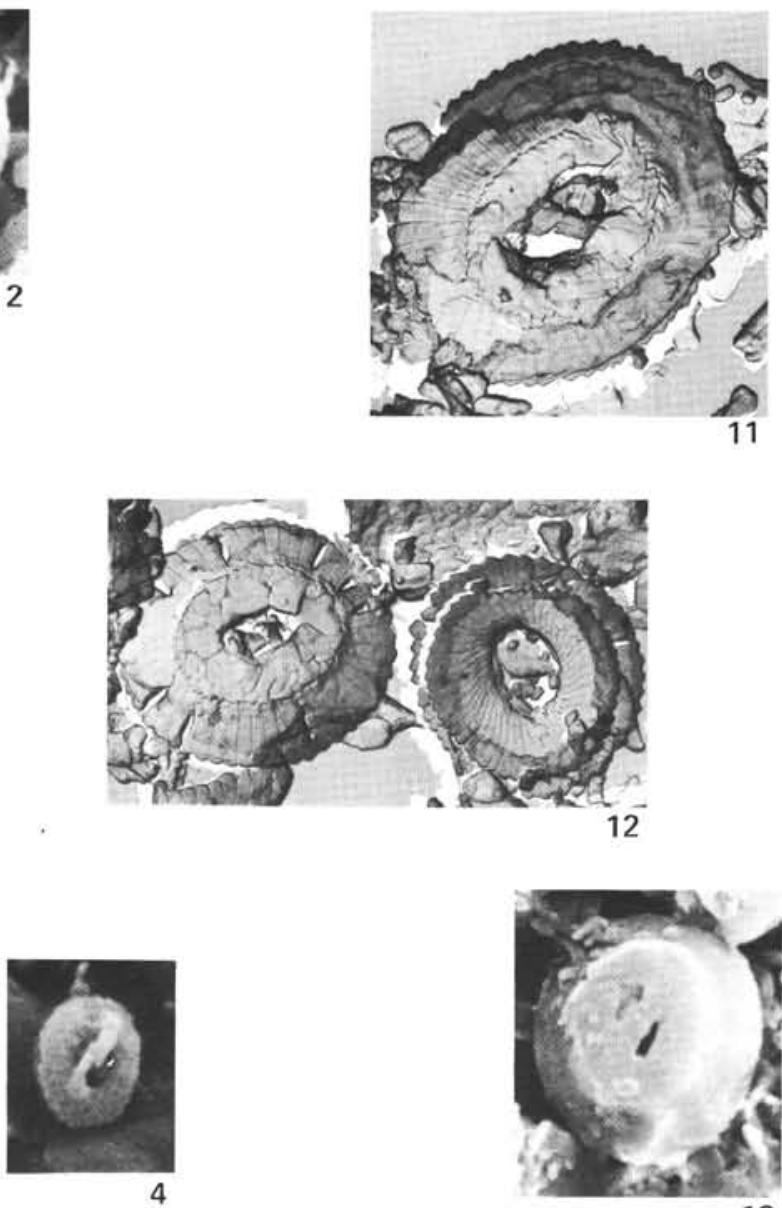

13
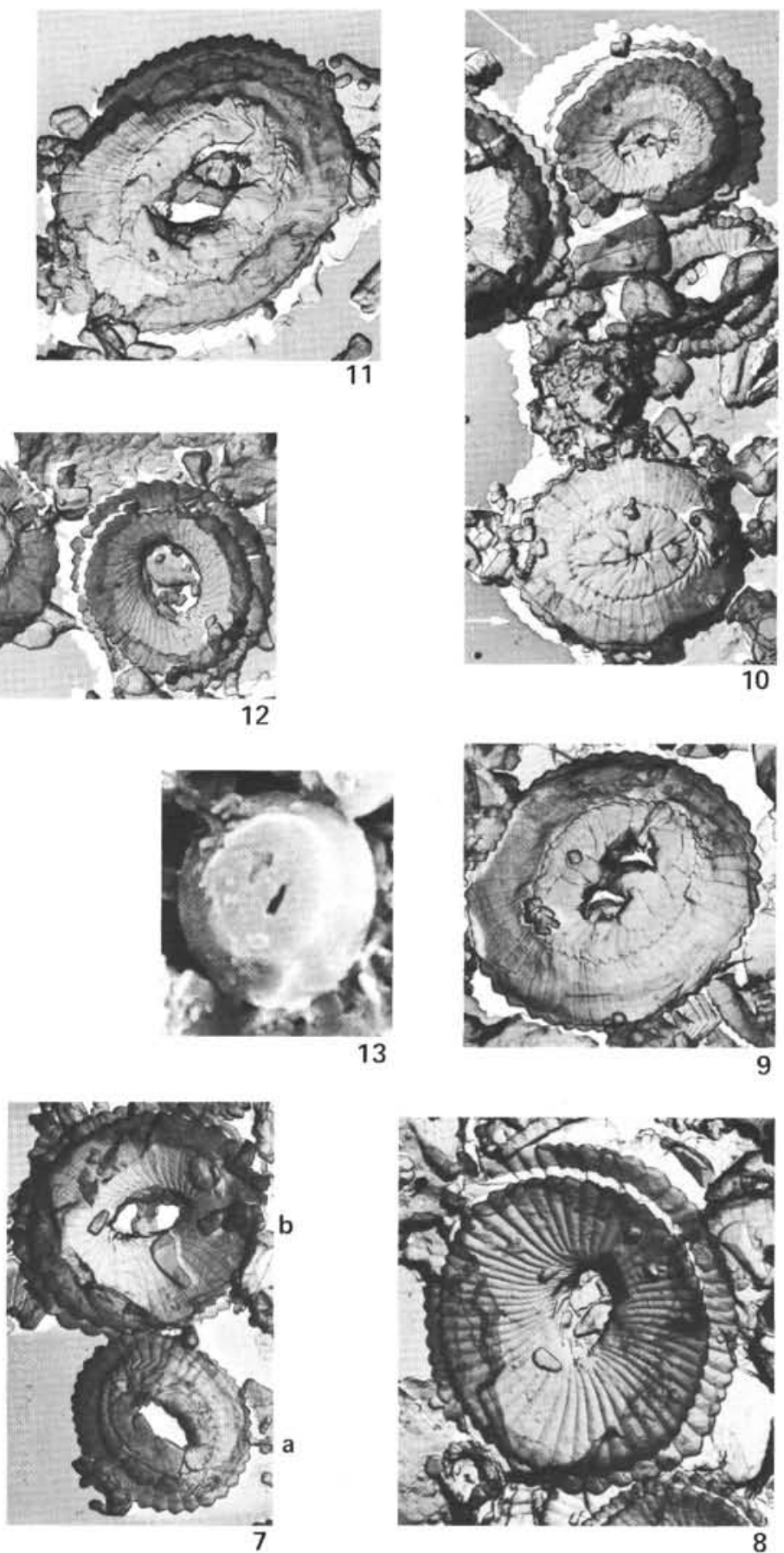

Plate 2. (TEM $=$ transmission electron microscope; $\mathrm{SEM}=$ scanning electron microscope.) 1-3a. Gephyrocapsa oceanica, $\times 6000, \mathrm{SEM}(1-2)$ Sample 549A-2-1, 3-6 cm (1, G. oceanica s.s.; 2, G. oceanica "W"), (3a) G. oceanica "W," Sample 549A-3-1, 2-5 cm. 3b-5. Gephyrocapsa caribbeanica, (3b-4) Sample 549A-3-1, 2-5 cm, $\times 6000$ SEM (3b, large form; 4, small form), (5) Sample 548-8-1, 69-70 cm, large forms, two spheres, $\times 4500$, TEM. 6-7a. Gephyrocapsa producta, $\times 4500$, (6) Sample 548-11-5, 73-75 cm, SEM, (7a) Sample 548-15-2, 44-45 cm, TEM. 7b-13. Gephyrocapsa doronicoides, $\times 4500$, (7b-9) var. 1, TEM (7b, Sample 548-15-2, 44-45 cm; 8, Sample 548-14,CC; 9, Sample 548-13-4, 35-38 cm), (10-12) Sample 548-14,CC, TEM (10, var. 2; 11, var. 3; 12, var. "lacunosa"), (13) var. 4, Sample 549A-3-1, 2-5 cm, SEM. 

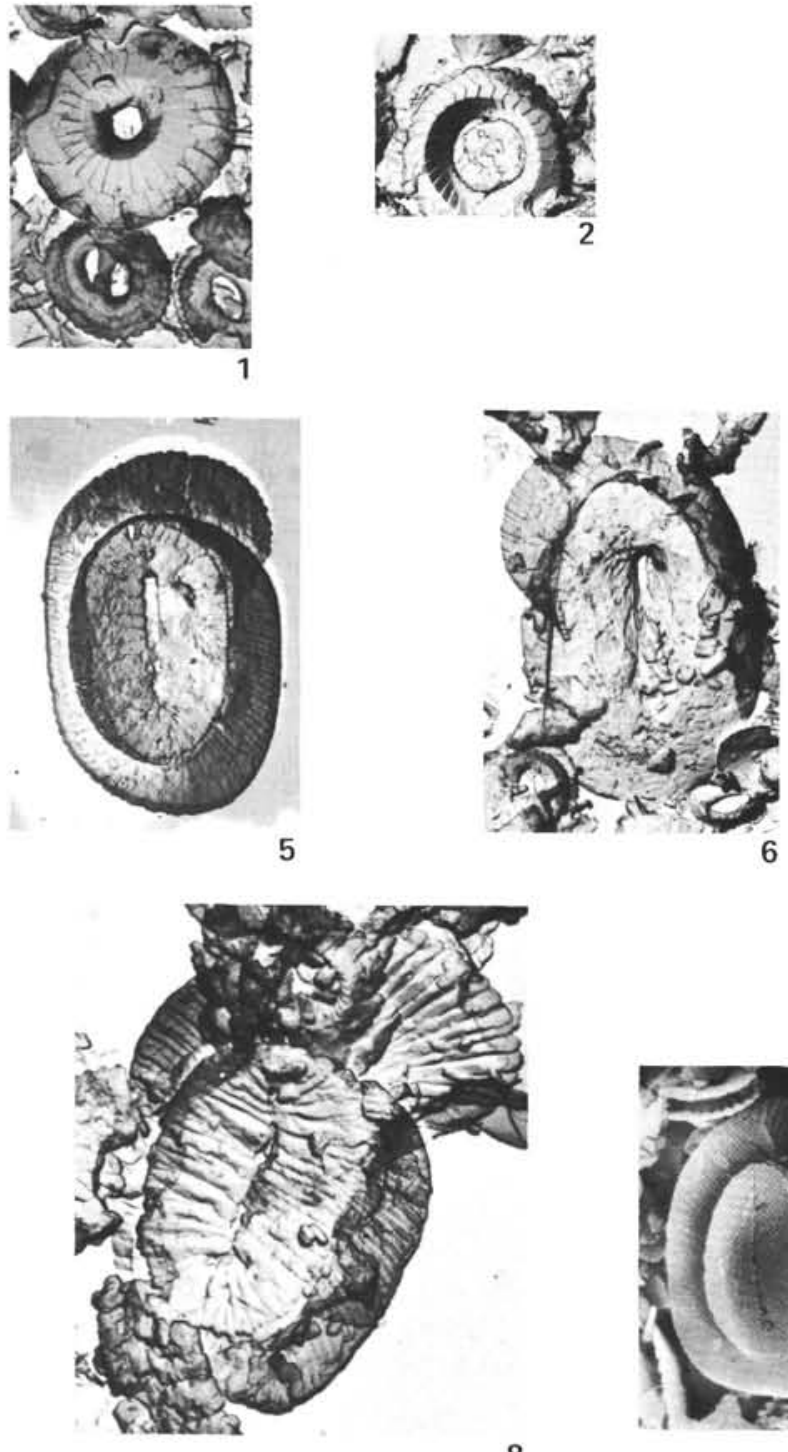

8

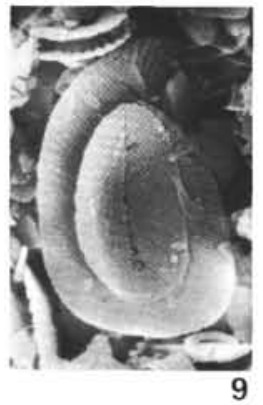

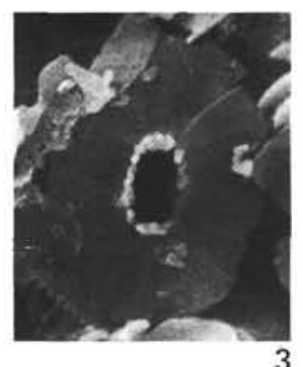
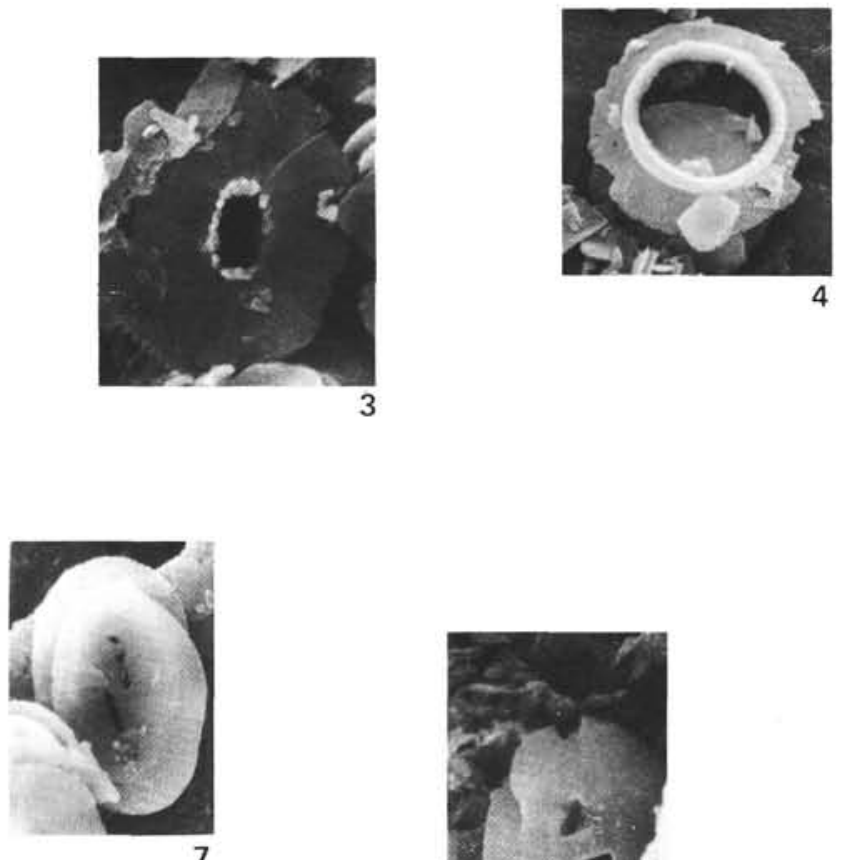

7

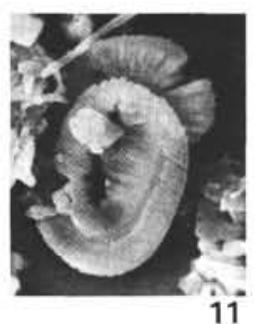

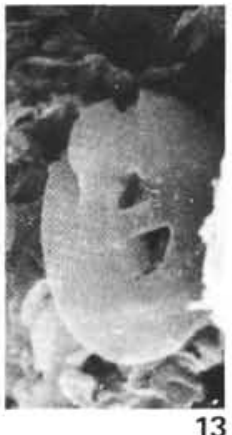

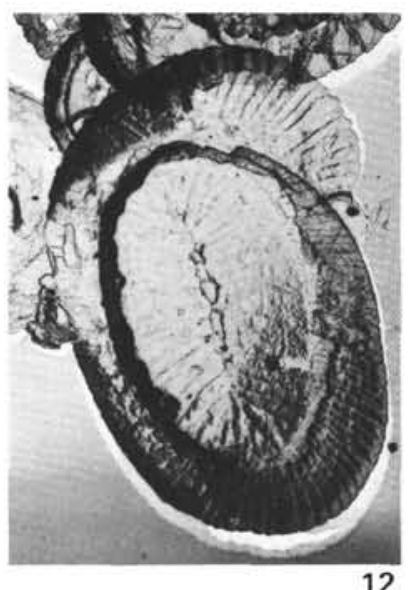

Plate 3. (TEM $=$ transmission electron microscope; $\mathrm{SEM}=$ scanning electron microscope.) 1-2. Umbilicosphaera sibogae, Sample 548-9-2, 60$61 \mathrm{~cm} ; \times 3000$, TEM, (1) form with a small central opening, and Gephyrocapsa oceanica s.s., (2) form with a large central opening. 3. Umbellosphaera irregularis, Sample 549A-2-1, 3-6 cm, $\times 6000$, SEM. 4. Cyclolithella annula, Sample 549A-1-4, 20-23 cm, $\times 3000$, SEM. 5-6, 12. Helicopontosphaera kamptneri s. ampl. (two faces of the coccolith), Sample 548-5-2, 21-24 cm, $\times 3000$, TEM. 7. Helicopontosphaera wallichi, Sample 548-1-1, 0-3 cm, $\times 3000$, SEM. 8-10. Helicopontosphaera neogranulata, (8) Sample 548-8-5, 90-91 cm, $\times 4500$, TEM, (9-10) Sample 548-10,CC, $\times 3000$, SEM. 11, 13. Helicopontosphaera sellii, $\times 3000$, two faces of the coccolith, Sample 548-11-5, 17-24 cm, SEM. (12) Sample 548-14,CC, TEM. 

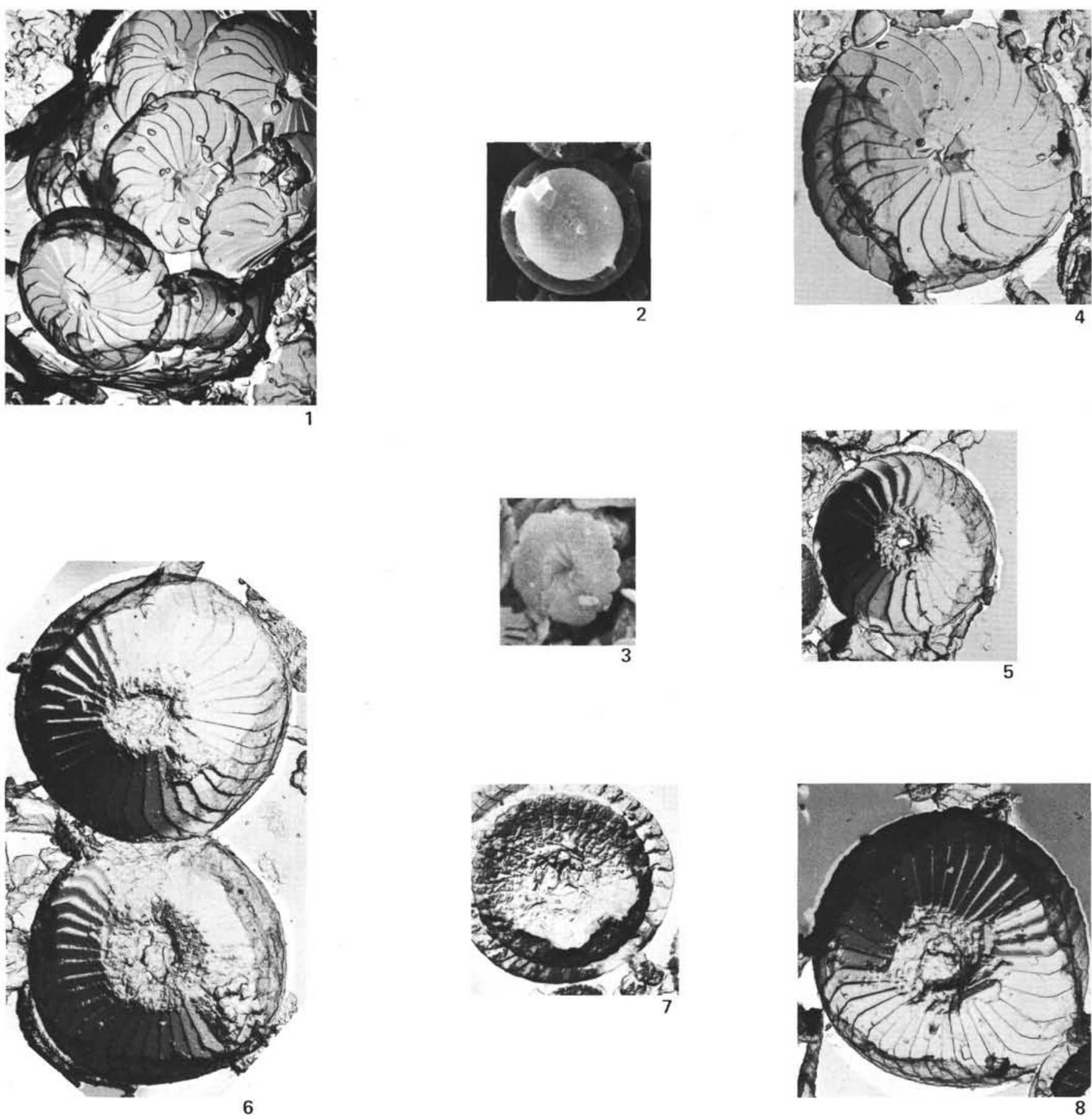

Plate 4. (TEM = transmission electron microscope; $\mathrm{SEM}=$ scanning electron microscope.) 1-4. Cyclococcolithina leptopora, (1-2) var. 1, two faces of coccolith (1, Sample 548-11-5, 17-24 cm, ×4500, TEM; 2, Sample 548-1-1, 0-3 cm, $\times 3000$, SEM), (3) var. 2, Sample 549A-3-5, 80-85 $\mathrm{cm}, \times 6000$, SEM, (4) s.s., Sample 548-14,CC, $\times 4500$, TEM. 5-8. Cyclococcolithina macintyrei, Sample 548-15-2, 44-45 cm, $\times 3000$, TEM, (5) C. cf. macintyrei, (6-8) C. macintyrei s.s. 